\title{
A CRIMINALIZAÇÁO DOS PROTESTOS DO MOVIMENTO PASSE LIVRE EM SÃO PAULO (2013-2015)
}

\section{Frederico de Almeida}

https://orcid.org/0000-0002-6857-6220

\section{Filipe Jordáo Monteiro}

https://orcid.org/0000-0002-6360-0877

\section{Afonso Smiderle}

https://orcid.org/0000-0003-1784-3701

(1) Departamento de Ciência Política do Instituto de Filosofia e Ciências Humanas da Universidade Estadual de Campinas (Unicamp), pesquisador do Centro de Estudos Internacionais e de Política Contemporânea e coordenador do Laboratório de Estudos de Política e Criminologia (PolCrim/ Unicamp), Campinas - SP, Brasil. E-mail: fnralmeida@gmail.com

2) Pesquisador associado ao Laboratório de Estudos de Política e Criminologia da Universidade Estadual de Campinas (PolCrim/Unicamp),

Campinas - SP, Brasil. E-mail: fjordaomonteiro@gmail.com

(3) Pesquisador associado ao Laboratório de Estudos de Política e Criminologia da Universidade Estadual de Campinas (PolCrim/Unicamp),

Campinas - SP, Brasil. E-mail: smiderle@gmail.com

DOI: $10.1590 / 3510211 / 2020$

\section{Introdução}

Este artigo apresenta resultados de uma pesquisa $^{1}$ que teve por objetivo compreender os processos de criminalização e os sentidos de práticas e discursos de instituiçôes e agentes de segurança e justiça criminal, movimentos sociais, manifestantes e imprensa, empiricamente verificados na análise de dinâmicas, discursos, documentos e procedimentos administrativos e judiciais de repressão dos protestos. O estudo é focado especificamente nos protestos liderados pelo Movimento Passe Livre (MPL) em junho de 2013 e janeiro de 2015 na cidade de São Paulo.

Para atingir os objetivos de pesquisa, optou-se por uma análise qualitativa, aberta e interpretativa:

Artigo recebido em: 18/01/2019

Aprovado em: 30/08/2019 aberta, no sentido de que perguntas e referências teóricas iniciais orientam a entrada em campo e a coleta de dados, mas não impedem que a pesquisa considere e inclua novas questôes que surjam de dados não esperados (Becker, 2014); interpretativa, no sentido de que busca reconstruir os sentidos de ações sociais dos diferentes agentes e instituiçóes que interagem ao longo dos fluxos dos processos de criminalização do protesto, articulando os sentidos subjetivos dos sujeitos investigados, os sentidos objetivos dos documentos institucionais, e os processos, contextos e configuraçôes históricas, sociais e políticas nas quais eles são produzidos e que escapam à consciência daqueles agentes (Weber, 1999; Yanow, 2003, 2015).

Para a delimitação temporal e espacial do objeto de pesquisa, optou-se pela concentração de esforços na análise dos processos de criminalização dos protestos convocados pelo MPL na cidade de São Paulo, em junho de 2013 e janeiro de 2015. 
Embora o período permitisse a análise de outros eventos de protestos e eventuais processos de criminalização na mesma localidade (protestos contra a Copa do Mundo de 2014, greve e invasáo da sede do Sindicato dos Metroviários no mesmo ano etc.), foi necessária uma economia de recursos e esforços de pesquisa, dada a complexidade desse ciclo de protestos iniciado em 2013 (Bringel e Pleyers, 2015; Tatagiba, 2014) e a dificuldade de obtenção de dados suficientes para uma análise que contemplasse toda a diversidade de atores, movimentos, pautas e processos de criminalizaçáo no período. Além disso, os marcos temporais estabelecidos em junho de 2013 e janeiro de 2015 correspondem a duas mobilizaçóes importantes do MPL na cidade de São Paulo: a que serviu de estopim para as chamadas "jornadas de junho", em 2013, e a primeira volta do movimento às ruas, após a difusão anterior da onda de protestos pelo país, dois anos depois.

\section{Dados e métodos}

Foram analisados ao todo quatro inquéritos policiais e duas açôes penais, relativas aos protestos ocorridos nos dias 6, 11 e 13 de junho de 2013 (identificados como Procedimentos 1 a 6, ordenados de acordo com a data dos protestos); há também um quinto inquérito policial (Procedimento 7) - que teve bastante repercussão na mídia -, apelidado pelos advogados entrevistados e pela própria imprensa de "inquérito black bloc" e que buscava investigar de maneira pretensamente global atos de violência e a constituição de organizações criminosas para a prática de atos de vandalismo nos protestos como um todo, não se relacionando a nenhum dia ou evento de protesto específico. O Quadro 1 sintetiza as informaçóes básicas dos procedimentos selecionados:

Os procedimentos foram acessados a partir do contato com advogados ligados ao MPL e atuantes na defesa técnica de manifestantes presos naquele período, e foram identificados por aqueles profissionais como o conjunto total dos procedimentos criminais resultantes de prisóes de manifestantes nos protestos de junho, sob seu acompanhamento profissional, embora nem todos os acusados fossem manifestantes orgânicos do Movimento ${ }^{2}$. Embora todos eles tenham sido considerados para análises mais gerais de suas características e resultados, os Procedimentos 2 e 3 foram excluídos da análise detalhada de sua tramitaçáo, já que não foi possível acessar seu conteúdo completo, e o Procedimento 7 foi analisado de acordo com suas especificidades.

Também foram analisadas 14 notas publicadas no site do MPL; 33 notícias publicadas no site da Secretaria de Segurança Pública do Estado de São Paulo (SSP); e oito notas coletadas no site do Ministério Público do Estado de São Paulo (MPSP). Esses documentos foram selecionados por meio da leitura sistemática de todas as notas publicadas naqueles sites durante o período abrangido pela pesquisa, a partir da qual foram identificadas aquelas que diziam respeito ao tema dos protestos ocorridos naquele intervalo temporal.

A análise incluiu também as entrevistas realizadas com oito advogados que atuaram na defesa de manifestantes ou do direito à manifestação; três manifestantes que participaram de protestos no período e que tiveram interaçóes com instituiçóes de justiça e segurança; um policial militar com experiência em policiamento de protestos; e dois juízes com experiências diversas com a repressão a protestos. Advogados, juízes e o policial foram selecionados para entrevistas por meio da amostragem do tipo "bola de neve" (Biernacki e Waldorf, 1981), a partir de contatos iniciais com informantes e pessoas dos círculos de relaçóes pessoais e profissionais dos membros da equipe de pesquisa. Os manifestantes foram selecionados tanto por amostragem "bola de neve" quanto a partir de sua identificaçáo nos procedimentos analisados pela pesquisa. ${ }^{3}$

Secundariamente, foram buscadas notícias de jornais e documentos complementares, relativos a eventos (datas) de protestos específicos, procedimentos criminais com repercussão pública ou sobre a questão dos protestos e sua repressão, em geral. Tanto as entrevistas quanto os documentos tiveram seus conteúdos analisados por meio de procedimentos de codificação (Saldaña, 2009) e lexicometria (Conde, 2015), com auxílio do software de análise qualitativa Atlas.ti. A observaçâo participante em dois eventos de protestos do MPL em $9 \mathrm{e}$ 16 de janeiro de 2015 também forneceu subsídios para a análise. 


\section{Quadro 1}

Procedimentos Criminais Decorrentes de Protestos Envolvendo Militantes ou Simpatizantes do MPL

\begin{tabular}{|c|c|c|c|c|c|c|c|}
\hline $\begin{array}{l}\text { Data do } \\
\text { protesto }\end{array}$ & Número & Tipo & $\begin{array}{l}\text { Número de } \\
\text { acusados }\end{array}$ & $\begin{array}{l}\text { Crimes } \\
\text { imputados }\end{array}$ & $\begin{array}{l}\text { Prisáo em } \\
\text { flagrante }\end{array}$ & $\begin{array}{l}\text { Presos } \\
\text { liberados }\end{array}$ & Situaçáo \\
\hline \multirow[t]{3}{*}{$6 / 6 / 2013$} & 1 & $\begin{array}{l}\text { Ação } \\
\text { penal }\end{array}$ & 2 & Dano & Sim & Sim & $\begin{array}{l}\text { Suspensão condicional } \\
\text { da pena (acordo de } \\
\text { transaçáo penal) }\end{array}$ \\
\hline & 2 & $\begin{array}{l}\text { Inquérito } \\
\text { policial }\end{array}$ & 4 & Dano & Sim & Sim & $\begin{array}{l}\text { Em andamento } \\
\text { (aguarda produção de } \\
\text { provas) }\end{array}$ \\
\hline & 3 & $\begin{array}{l}\text { Inquérito } \\
\text { policial }\end{array}$ & 1 & Desacato & Sim & Sim & $\begin{array}{l}\text { Arquivado (não } \\
\text { demonstraçáo de } \\
\text { materialidade ou } \\
\text { autoria) }\end{array}$ \\
\hline \multirow[t]{2}{*}{$11 / 6 / 2013$} & 4 & $\begin{array}{l}\text { Inquérito } \\
\text { policial }\end{array}$ & 10 & $\begin{array}{l}\text { Dano } \\
\text { Incêndio } \\
\text { Associação } \\
\text { criminosa }\end{array}$ & Sim & Sim & $\begin{array}{l}\text { Em andamento } \\
\text { (aguarda produção de } \\
\text { provas) }\end{array}$ \\
\hline & 5 & $\begin{array}{l}\text { Ação } \\
\text { penal }\end{array}$ & 2 & $\begin{array}{l}\text { Dano } \\
\text { Lesão } \\
\text { corporal } \\
\text { Desacato }\end{array}$ & Sim & Sim & $\begin{array}{l}\text { Absolvição (provada a } \\
\text { não participaçãa dos } \\
\text { réus nos fatos) }\end{array}$ \\
\hline $13 / 6 / 2013$ & 6 & $\begin{array}{l}\text { Inquérito } \\
\text { policial }\end{array}$ & 5 & $\begin{array}{l}\text { Dano } \\
\text { Incitação ao } \\
\text { crime } \\
\text { Associação } \\
\text { criminosa }\end{array}$ & Sim & Sim & $\begin{array}{l}\text { Concluído } \\
\text { (encaminhado ao } \\
\text { Ministério Público, } \\
\text { com relatório } \\
\text { conclusivo da } \\
\text { materialidade do crime } \\
\text { e de sua autoria) }\end{array}$ \\
\hline $\begin{array}{l}\text { Sem data } \\
\text { específica }\end{array}$ & 7 & $\begin{array}{l}\text { Inquérito } \\
\text { policial }\end{array}$ & Indefinido & $\begin{array}{l}\text { Associação } \\
\text { criminosa }\end{array}$ & Não & $\begin{array}{l}\text { Não se } \\
\text { aplica }\end{array}$ & Arquivado \\
\hline
\end{tabular}

Fonte: Conflito político e sistema de justiça: a judicialização criminal dos protestos urbanos em São Paulo (2013-2015).

\section{Referenciais teóricos e analíticos}

Para guiar essa análise aberta e interpretativa, optou-se pela ideia de processo de criminalização como guia de investigação; segundo essa concepção, a criminalização ocorre ao longo das sucessivas etapas dos procedimentos formais da justiça criminal (Lacey, 2007). De acordo com essa concepção de criminalização, fazem parte desse processo a ação repressiva da polícia no momento dos protestos, realizada sob as alegaçôes intercambiáveis ou sobrepostas de garantia da lei e manutenção da ordem (P. A. J. Waddington, 1991, 1994, 1999); os discursos oficiais de delegados, promotores, advogados e juízes a respeito das possíveis interpretaçóes do caráter criminoso das práticas e dos sujeitos acusados; e também os discursos de resistência e reinterpretação opostos por militantes e seus advogados.

Segundo a abordagem de Lacey $(2007,2013)$, considera-se que o fluxo de procedimentos formais 
serve de base para a incidência de discursos políticos e da mobilização dos elementos propriamente legais sobre crime e responsabilização, que produzem a criminalização ao longo daqueles procedimentos, articulando, assim, a construção legal à construção social do crime. A autora diferencia, portanto, o que chama de construçáo legal do crime - que corresponde às mobilizaçôes de elementos legais das definiçóes de crime, tanto no estabelecimento de novas previsóes legais como em sua mobilização em um processo criminal - da construção social do crime que corresponde aos sentidos atribuídos a condutas tidas como criminosas.

Em um mesmo sentido, Misse (2008, 2010a, 2014) especifica operadores analíticos capazes de diferenciar os processos sociais de criminalização: a criminalização propriamente dita, considerada como a normatização de condutas moralmente reprováveis em códigos institucionais de direito, ou seja, a definição ao mesmo tempo moral e jurídica de certa conduta como sendo legalmente um crime; a criminação de um evento, entendida como o conjunto de processos interpretativos sucessivos sobre um mesmo fato, a fim de enquadrá-los na classificação legal do que é institucionalizado como crime; a incriminação do sujeito autor da conduta incriminada, ou seja, a responsabilização do indivíduo pelas conduta interpretadas como crime, de acordo com os códigos jurídicos e morais institucionalizados. Um quarto operador analítico utilizado por Misse é o da sujeição criminal, entendida como processo de construção de tipos sociais preventivamente propensos à prática criminosa, processo social que extrapola o limite dos procedimentos e instituiçóes judiciais e policiais, alimentando-os e por eles sendo alimentado. ${ }^{4}$

Embora a perspectiva de Lacey seja útil para a organização do trabalho de pesquisa e análise a partir do fluxo de criminalização, a diferenciação proposta pelos operadores analíticos de Misse permite compreender melhor os diferentes processos de criminalização, que ocorrem em momentos distintos (fases) do fluxo procedimental formal.

Nesse aspecto, as perspectivas de Lacey e de Misse foram articuladas em um diálogo do presente trabalho com a farta produção brasileira sobre os fluxos da justiça criminal, que busca investigar a incidência de variáveis legais, extralegais e organizacionais nos processos de criminalizaçáo por meio da reconstituição do fluxo de procedimentos e pessoas que atuam nesse processo nas diferentes organizaçóes do sistema de justiça criminal (Misse, 2011; Ratton, Torres e Bastos, 2011; Vargas, 2007; Vargas e Rodrigues, 2011). Além disso, esse diálogo permite conceber o processo de criminalização dos protestos para além dos procedimentos formais-legais, uma vez que, em uma dinâmica política contenciosa como a dos protestos, a própria definição do que é crime e do que é legitimo em termos de ação política pode ser objeto do conflito político (P. A. J. Waddington, 2010).

Portanto, podemos estabelecer que a criminalização é resultado da disputa entre diferentes atores (militantes, policiais, advogados, juízes, promotores, imprensa) em torno da classificaçáo jurídica e moral dos atos de protesto como crime ou como manifestação política legítima. Segundo essa conceituação ampla, a criminalização vai acontecer em qualquer momento do fluxo da justiça criminal ou de suas operações específicas (criminalização, criminação, incriminação ou sujeição criminal) sempre que os discursos que operam essa tradução a partir de categorias do direito penal prevalecerem sobre os discursos que buscam a classificação dos protestos em termos de direitos fundamentais e liberdades políticas. Esta é a principal hipótese de trabalho.

\section{O arcabouço legal da criminalização}

Considerando os operadores analíticos sugeridos por Misse (2008), a primeira conclusão da pesquisa sobre os procedimentos selecionados é a de que o processo de criminalização, pensado em termos genéricos, ocorre sem uma criminalização em sentido estrito, ou seja, sem a criaçáo legislativa de novos tipos penais que busquem positivar uma condenação moral especificamente voltada à ação política dos protestos ou à própria existência de movimentos sociais contestatórios.

Nos procedimentos analisados, os crimes imputados aos manifestantes presos ou investigados são todos eles originários da legislação penal ordinária. A cinco dos sete procedimentos foi aplicado, no momento da 
prisão, o artigo 163 do Código Penal (Dano), sendo que apenas um dos procedimentos apresenta somente este crime (Procedimento 2). Nos outros procedimentos há acusação por outros crimes no momento da prisão, sendo em um deles (Procedimento 5) os artigos 331 (Desacato) e 129 (Lesão corporal); em outros dois (Procedimentos 4 e 6), o artigo 288 (Associação criminosa), sendo em um deles (Procedimento 4) acrescido o artigo 250 (Incêndio) e, em outro (Procedimento 6), o artigo 286 (Incitação ao crime), todos dispositivos do Código Penal. No Procedimento 3 a acusação é apenas pelo crime de desacato. Apenas no Procedimento 5 uma pessoa é definida como vítima (nesse caso, de lesão corporal).

Se considerarmos as divisóes temáticas do Código Penal brasileiro, veremos que os crimes atribuídos pelas autoridades policiais aos atos e ativistas de protestos são classificados em três principais títulos: "crimes contra o patrimônio" (dano e dano qualificado, este relativo ao patrimônio público); "crimes contra a paz pública" (incitação ao crime e associação criminosa); "crimes contra a administração pública" (desacato); "crimes contra a incolumidade pública" (incêndio); "crimes contra a pessoa" (lesão corporal). A prevalência da criminação dos atos praticados em protestos como crimes patrimoniais, contra a paz pública e contra a administração pública sugere que a criminalizaçáo dos protestos se dá no sentido de afirmação e defesa da ordem econômica (patrimônio), social (paz) e política (administração) contra a política contenciosa expressa pelos protestos. Além de confirmar a hipótese da pesquisa, esse achado se alinha com resultados de outras pesquisas sobre o funcionamento da justiça criminal, que destacam sua atuação como predominantemente voltada à defesa da propriedade, da circulação da riqueza e de concepções autoritárias de ordem (Lima, Sinhoretto e Bueno, 2015; Sinhoretto e Lima, 2015).

A crítica à defesa da ordem e do patrimônio contra o direito de manifestação aparece no discurso do MPL; em uma nota na qual critica a decisão judicial que negou liberdade provisória a um manifestante, o movimento afirma que

O teor da decisão deixa claro que o Judiciário não tem provas da acusação que é feita contra
Paulo, mas o mantém preso simplesmente por participar do protesto. Na visão do magistrado, todo protesto depois de junho seria uma "quebra da ordem pública”. Nas palavras dele: "São alguns poucos, em relação às centenas de milhares que anteriormente participavam, e estes, queira ou não, causam enorme prejuízo para a coletividade, bloqueando avenidas importantes, rodovias, e facilitando a ação de grupos de vândalos e malfeitores. Inquestionável que tais atitudes provocam intensa perturbação $\mathrm{da}$ ordem pública." ("Sobre as contínuas arbitrariedades da PM e do Judiciário: a quem serve o direito penal?", nota do MPL de 31 de outubro de 2013).

Essa crítica do MPL chama atenção para a possibilidade de que juízes e promotores compartilhem suas percepções sobre a legitimidade dos protestos e apliquem esquemas classificatórios idênticos ou semelhantes, em geral baseados em alguns poucos dispositivos legais da legislação penal comum apesar do predomínio da discricionariedade policial na classificação dos atos de protesto e das possibilidades formais de defesa e reclassificação jurídica ao longo do procedimento judicial, que serão analisadas adiante.

Isso não quer dizer que a onda de protestos de junho de 2013 não tenha gerado demandas por criminalização em sentido estrito. Foi após aquele período que começou a tramitar a Lei Antiterrorismo (Lei n. 13.260/2016, originária do Projeto de Lei n. 2.016/2015). Oficialmente justificada pelo governo como pensada para ameaças terroristas internacionais aos eventos da Copa do Mundo de Futebol e das Olimpíadas que aconteceriam no Brasil, mas também como compromisso assumido pelo país em função de iniciativas de combate à lavagem de dinheiro, a aprovação dessa lei foi vista como uma ameaça ao direito de protesto e um esforço de criminalização dos movimentos sociais no Brasil pós-2013 (Artigo 19, 2014; France, 2017; Tinoco, 2016). O texto original do projeto de lei foi alterado para salvaguardar especificamente os movimentos sociais, e não há notícia de manifestantes presos e/ou condenados com base nessa lei, embora sua aplicação já tenha sido cogitada por autoridades. ${ }^{5}$ 
Outra norma aprovada no período e que deve ser entendida no conjunto da produçáo legislativa associada à repressão dos protestos foi a Lei das Organizaçóes Criminosas (Lei n. 12.850/2013, originária do Projeto de Lei n. 6.578/2009). Embora sua tramitação tenha sido iniciada antes do período abarcado pela pesquisa, sua aprovação no contexto contencioso de 2013 motivou questionamentos sobre sua aplicabilidade a movimentos sociais (Justiça Global, Instituto de Defensores de Direitos Humanos e Centro de Assessoria Jurídica Popular Mariana Criola, 2013). A referida lei não trata expressamente de movimentos sociais, mas alterou a criminalização existente para a "formação de quadrilha" (verificada nos procedimentos analisados pela pesquisa) e introduziu meios especiais de investigação que posteriormente ficariam conhecidos nas práticas judiciais e policiais anticorrupção, como a delação premiada. Apesar de a pesquisa não ter verificado sua incidência nos procedimentos analisados, os receios de ativistas de direitos humanos se viram confirmados com a aplicação futura daquela lei a manifestantes dos protestos de 2013 no Rio de Janeiro ${ }^{6}$ e ao Movimento dos Trabalhadores Sem-Terra, em Goiás, em 2016. ${ }^{7}$

Por fim, é preciso chamar atenção para o esforço de produção legislativa como reação aos protestos que, embora não se deem no âmbito estritamente criminal, buscam sancionar certas condutas características de ações de contestação política observadas nos protestos de junho de 2013. Referimo-nos especialmente a legislaçôes administrativas de estados e municípios, entes federativos que, embora não tenham competência para legislarem em matéria penal, buscaram produzir novas leis administrativas que caracterizam o que Fernandez (2008) chama de controle social soft-line dos protestos (que bem poderia ser traduzido como "linha suave"): a proibição de uso de máscaras em protestos ${ }^{8}$; as restriçóes a manifestaçóes em vias públicas por meio de mudanças na legislação municipal ${ }^{9}$ ou no Código de Trânsito Brasileiro ${ }^{10}$ etc. (em oposição ao que o autor chama de controle social hard-line, ou "linha dura", que é a repressão direta, por meio de contenção física, prisóes etc.). No caso da cidade e do estado de São Paulo, iniciativas de controle social por meio de legislação administrativa foram tentadas após os protestos de 2013, a exemplo da proibição do uso de máscaras em âmbito municipal (Projeto de Lei n. 675/2013) e estadual (Projeto de Lei n. 50/2014) (Artigo 19, [s.d.], 2014).

\section{Intensidades e dinâmicas dos fluxos de criminalização}

Passamos agora à análise dos procedimentos criminais selecionados, com base na concepção de fluxo do processo de criminalização. Se pensarmos no fluxo formal do processo judicial criminal, temos os seguintes agentes, instituiçôes e relações formais entre elas: prisóes em flagrante no momento dos protestos pela Polícia Militar (PM) levam à apuração da possível prática de crimes pela Polícia Civil (PC), crimes estes previamente definidos em lei; a partir de relatório do inquérito policial, se entender que há indícios de crime, o Ministério Público (MP) oferece denúncia que, se aceita pelo Judiciário, dá início à ação penal, na qual é realizada a instrução criminal, com produção de provas e exercício do contraditório entre acusação (MP) e defesa (advogados), e que resulta em uma sentença; mesmo sendo um procedimento administrativo e pré-judicial, o inquérito policial se submete a controle judicial, e o MP pode solicitar a realização de diligências nessa fase de investigação; os advogados de defesa podem atuar em qualquer momento desse fluxo, embora sua presença seja obrigatória apenas na fase da ação penal; é importante dizer, ainda, que o inquérito policial não depende da ocorrência prévia de uma prisão em flagrante delito pela PM, assim como o MP pode oferecer denúncia, realizar investigação diretamente e dar início à ação penal sem a realização prévia do inquérito policial; por fim, deve-se considerar ao final desse fluxo a possibilidade de recursos contra a sentença judicial, bem como de recursos ao longo do fluxo que levam a questão a tribunais de segunda instância.

Esquematicamente, este fluxo pode ser representado conforme Figura 1, abaixo.

Em um segundo momento, porém, podemos avançar no desenho desse esquema de relaçóes ao verificar empiricamente quais são os agentes $\mathrm{e}$ as instituições que efetivamente atuam no proces- 


\section{Figura 1 \\ Fluxo de Instituiçóes e Procedimentos de Justiça Criminal}

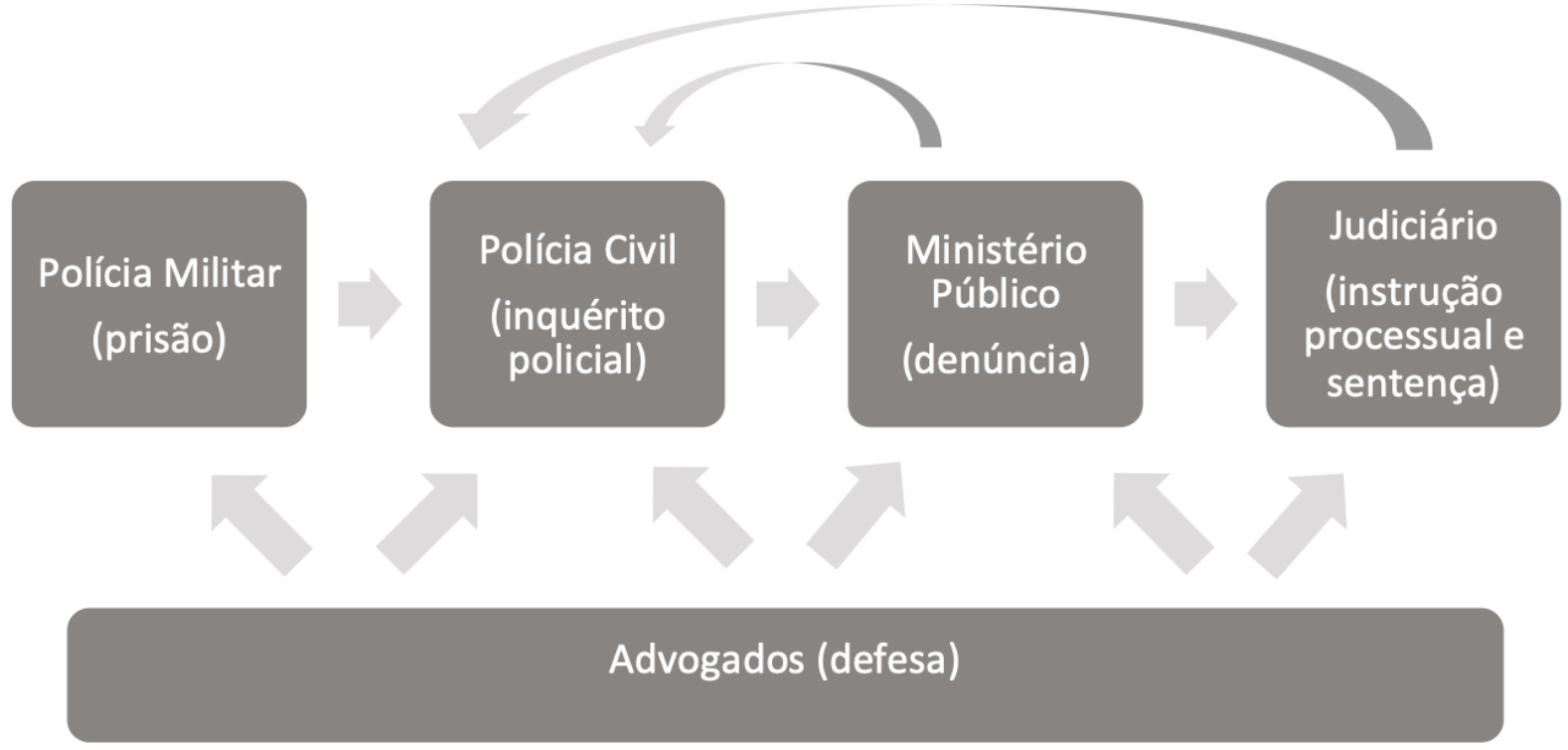

Fonte: Conflito político e sistema de justiça: a judicialização criminal dos protestos urbanos em São Paulo (2013-2015).

so de criminalização, considerado para além de sua dimensão formal, e em que medida o fazem. Se a existência de um espaço social relativamente autônomo de produção social depende de algum grau de inter-reconhecimento das posiçóes que compóem esse campo (Bourdieu, 2007) ${ }^{11}$, então a análise dos discursos de advogados atuantes nos protestos nos dão uma boa primeira aproximação das posições relevantes na produção social da criminalização do protesto.

A codificação das entrevistas realizadas com advogados atuantes nos protestos ${ }^{12}$ permitiu a quantificação dos códigos mais recorrentes nos discursos analisados. Como se vê no Gráfico 1, são as polícias as instituições mais referenciadas nos discursos analisados.

Ao analisarmos as práticas e instituiçóes citadas nos discursos analisados, veremos que o predomínio da PM no reconhecimento dos agentes analisados em relação ao espaço social da produçáo da criminalização se explica pela prevalência das prisóes como forma central de intervenção das instituições estatais nos protestos, como será mais bem analisado no tópico seguinte. Esse achado é condizente com outras análises comparadas, que identificam a centralidade da ação policial nas respostas estatais aos protestos (Della Porta, 1999; Fernandez, 2008; Lofthouse, 1996) e a alta discricionariedade da polícia na definição da legalidade dos protestos, no mesmo momento em que eles ocorrem (P. A. J. Waddington, 1991, 1994, 1999, 2010). Além disso, esse achado é compatível com análises sobre a centralidade das polícias militar e civil (com predomínio da primeira) na administração da justiça criminal em geral no Brasil, com alta discricionariedade na definiçáo dos sentidos concretos da legalidade, da ordem e da segurança públicas (Lima et al., 2015; Sinhoretto e Lima, 2015).

Dos sete procedimentos analisados, há cinco inquéritos policiais e duas ações penais (originadas, por sua vez, de inquéritos policiais); dois dos inquéritos (Procedimentos 2 e 4) ainda se encontravam em andamento no momento da coleta de dados; um deles (Procedimento 6) estava aguardando 


\section{Gráfico 1}

\section{Percentual da Ocorrência de Códigos Relacionados à Atuação de Instituiçóes nas Entrevistas com Advogados ${ }^{13}$}

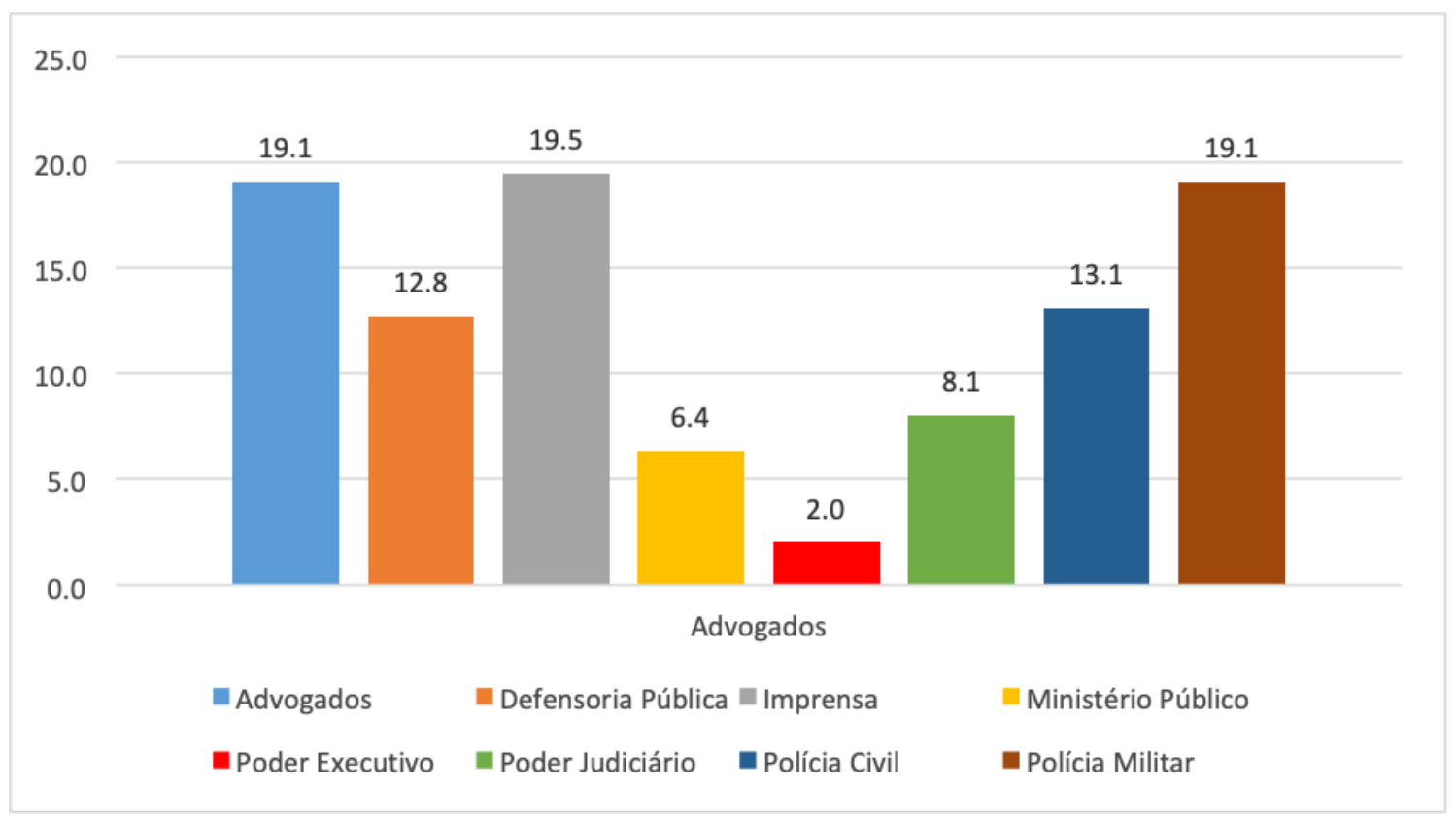

Fonte: Conflito político e sistema de justiça: a judicialização criminal dos protestos urbanos em São Paulo (2013-2015).

manifestação do MP sobre eventual propositura de ação penal; e os demais, arquivados (Procedimentos 3 e 7); as duas açóes penais instauradas estavam encerradas parcial (Procedimento 1, por suspensão condicional do processo, quando há uma admissão de culpa sem a continuidade do julgamento, submetendo-se o réu a penas alternativas e a comparecimento regular perante o juízo) ou definitivamente (Procedimento 5, por absolvição dos acusados por falta de provas de sua participação na conduta criminosa). Com exceção do "inquérito black bloc" (Procedimento 7), todos os procedimentos originaram-se de prisóes efetuadas pela PM durante os protestos, embora todas essas prisóes tenham sido revertidas, em algum momento, pelo pagamento de fiança ou decretação de liberdade provisória.

Ainda que a amostra de procedimentos analisados seja relativa apenas àqueles que tiveram acompanhamento jurídico pelos advogados do MPL - em contraste com a diversidade de atores e movimentos presentes nas ruas em junho de 2013 (Tatagiba, 2014) -, é digna de destaque a ínfima quantidade de procedimentos criminais resultantes dos protestos daquele período em relação ao número de prisóes realizadas e noticiadas pela imprensa, e também a desproporção entre a quantidade de inquéritos instaurados e o número de ações penais concluídas.

Apenas para se ter uma ideia da desproporção entre a dimensão das manifestações, o número de presos e o número de procedimentos criminais decorrentes de apenas um dia de protestos, uma reportagem do portal $U O L$ a respeito do ato do MPL do dia 13 de junho de 2013 fala em "dia de maior repressão pela PM” e informa que pelo menos 245 pessoas foram levadas presas a delegacias de polícia e 40 presos antes mesmo do início do ato (possivelmente, prisóes "para averiguação"); das levadas às delegacias, cinco foram autuadas por crimes de menor potencial ofensivo e liberadas, e outras cinco permaneceram presas por crimes de dano e formação de quadrilha. ${ }^{14}$

Esse fato - somado à verificação de prisão em flagrante em quase todos os casos coletados, a denúncias (verificadas nas notas do MPL e nas entrevistas 
com advogados) de "prisóes para averiguação" (sem flagrante ou fundamento legal) e às críticas do MPL e seus advogados ao Procedimento 7 como uma ferramenta de intimidação e monitoramento permanente de ativistas - reforça a ideia de um alto grau de discricionariedade das instituiçóes policiais, seja na prisão (PM), seja na condução de investigaçóes (PC).

De um lado, como já dito, o perfil dos procedimentos selecionados demonstra o predomínio do inquérito sobre as açóes penais, confirmando a prevalência da ação policial sobre a ação judicial na criminalização do movimento social. Por outro lado, o caso de absolvição por falta de prova de autoria, os inquéritos arquivados pelas mesmas razóes, as revogações de prisóes em flagrante (por arbitramento de fiança por delegado de polícia, ou concessão de liberdade provisória por juiz) e mesmo os inquéritos ainda em andamento aguardando a produção de provas demonstram um aparente contraponto à discricionariedade policial, representado pelas possibilidades de resistência à criminalização por meio do procedimento judicial formalmente baseado na presunção de inocência e no contraditório para a produção de provas.

Ao adaptarmos o primeiro fluxo às dinâmicas empiricmente verificadas na pesquisa, temos a representação gráfica apresentada pela Figura 2 (abaixo).

Essa ilustração esquemática busca ser fiel à realidade verificada na pesquisa sobre o fluxo processual da criminalização, que está fortemente concentrado nas açóes policiais, especialmente da PM, deixando pouca margem para a atuação do Judiciário e do $\mathrm{MP}$ - e, por consequência, dos advogados - e dos ritos próprios das fases judiciais. De acordo com o referencial analítico exposto anteriormente, e que busca extrapolar o âmbito legal-formal da criminalização, o maior predomínio da ação policial que pouco se desdobra em açóes penais com resultados condenatórios não quer dizer que não ocorra criminalização de manifestantes, movimentos sociais e açóes de protestos, uma vez que sentidos criminosos podem ser (como de fato foram) atribuídos por agentes estatais a condutas de ação política contenciosa.

Figura 2

Fluxo de Instituiçóes e Procedimentos de Justiça Criminal, de acordo com a Predominância de Cada Etapa

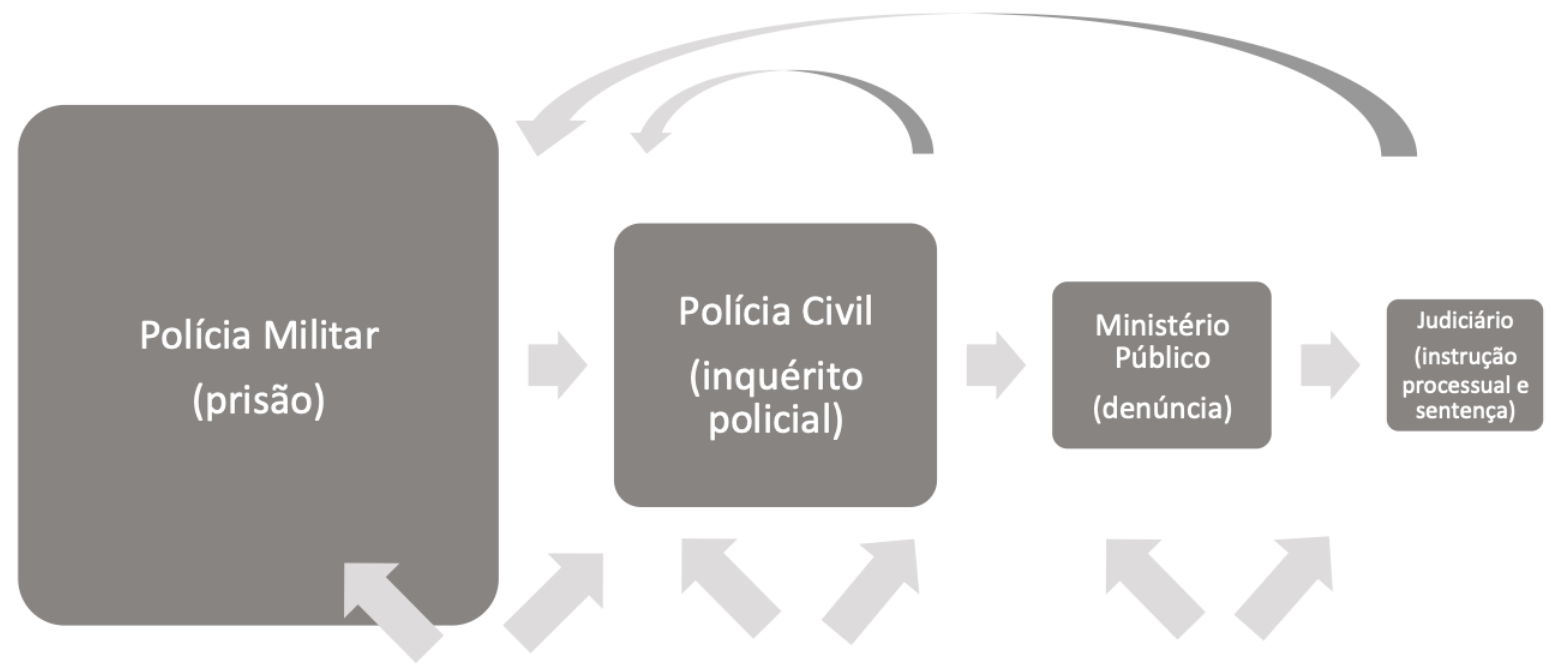

Advogados (defesa)

Fonte: Conflito político e sistema de justiça: a judicialização criminal dos protestos urbanos em São Paulo (2013-2015). 
Para compreender melhor a construção social desse fluxo empiricamente verificado, é necessário entender um pouco mais o desenrolar desses procedimentos, bem como os tipos de arranjos processuais e institucionais que explicam seus diferentes desdobramentos. Para isso, serão especificadas as práticas de criminação e incriminação das instituiçóes de segurança e justiça nos fluxos formais do processo de criminalização dos protestos.

\section{Criminaçáo e incriminaçáo pelas instituiçóes de segurança e justiça}

Processos de criminação e de incriminação foram identificados e analisados em relação a três momentos de sua ocorrência: a prisão e a dispersão de protestos pela PM nas ruas; a condução de inquéritos policiais pela $\mathrm{PC}$ e de açóes penais pelo Judiciário; e a investigação conduzida pela PC no chamado "inquérito black bloc".

\section{A prisão e a dispersão de protestos pela PM}

O papel central das polícias, especialmente da PM nos processos de criminação e incriminaçáo, decorre tanto da dinâmica dos protestos quanto de características estruturais e históricas do policiamento de protestos, em geral, e das polícias no Brasil, em especial. Na presente pesquisa, ele foi verificado pelo já mencionado alto número de prisóes em flagrante no momento dos protestos e no maior número de inquéritos abertos do que de açóes penais concluídas.

Questionado sobre como identificar um ato criminoso em meio a uma multidão, e de que modo agir para impedir o ato criminoso ou conter o criminoso sem afetar pessoas inocentes e sem impedir o direito de manifestação, o policial entrevistado apontou dois elementos em sua resposta, que se relacionam em sua percepção: a dissolução do indivíduo (e de sua racionalidade) em meio à "massa" (e à sua irracionalidade); e a inviabilidade operacional de uma ação localizada que busque extrair da multidão um indivíduo criminoso ou que busque conter isoladamente uma atitude criminosa. Veja o trecho a seguir:
Então você tem ali um grupo de pessoas, que eles perdem a individualidade. Eles agem muito, assim, de maneira irracional, maneira irracional... Muitas vezes tem essa questão. E para você identificar uma pessoa e tirar essa pessoa, pode-se dizer que não existe como, não existe como. Não tem nem treinamento para isso. [...] Qual que é a ideia da polícia numa situação dessa? Não é pegar o líder ou identificar, nem nada, você vai dispersar, é dispersar. Então você tem que identificar o quê? Tem um aglomerado gigante de pessoas, qual que é o local ali mais conveniente para que eles saiam, para que eles fujam, para que eles dispersem, onde é um local que eles vão correr, porque eu não posso nunca pensar em canto $A$, porque qualquer ser que você comece a pressionar, apertar e agir de maneira às vezes com a impressão de uma violência maior - bombas, gás, e ação do Choque, que ela causa às vezes temor da maneira... eh... como o policial age, você pode ter uma... uma... ação contrária violentíssima. Então você tem [que] dispersar, a ideia é dispersar. Então você nunca vai pensar em entrar no meio e pegar, porque não tem como, não tem como. Para você entrar e pegar, você vai ter que... você náo pode usar equipamentos letais, eu não posso pegar um policial, um grupo de policiais, pego lá dez caras, dez policiais e identifico que uma pessoa ali no meio, que ela pode estar armada. (Entrevista com policial militar).

Além da ocorrência de crimes no meio das manifestaçóes, constatou-se que o acesso ao espaço público para a realizaçáo dos protestos foi o principal móvel de conflitos entre PM e MPL. A demanda estatal por uma comunicação prévia à PM do trajeto que o ato seguiria vinha desde 2013, sendo que sua ausência era em geral alegada pela polícia como motivo para os distúrbios que ocorriam nas ruas da cidade naquele ano. Segundo a PM, isso era uma exigência de planejamento e da segurança dos próprios manifestantes e da possibilidade de circulação pela cidade da população que não participaria dos protestos $^{15}$ :

Queremos que os manifestantes exerçam seu direito de protestar, de se manifestar. E queremos 
assegurar que, a partir dessa reuniáo, as pessoas que trabalham e estudam, ou que querem voltar para casa, possam fazê-lo da melhor maneira possível. [...] Sabemos que a esmagadora maioria dos que estão indo às ruas quer apenas expressar sua opinião, e quer fazê-lo de maneira pacífica. Queremos garantir que assim aconteça. (Declaraçoos do então secretário de Segurança Pública do Estado de São Paulo, Fernando Grella Vieira, em coletiva de imprensa noticiada em nota da SSP do dia 16 de junho de 2013).

Segundo o MPL, porém, a recusa em informar o trajeto das manifestaçóes, num momento inicial, e o compromisso assumido posteriormente com a SSP de informar o trajeto minutos antes do início do protesto - mas após assembleia realizada no local para a tomada dessa decisão - colocavam-se em termos de se garantir o pleno exercício do direito de manifestação e do direito à cidade. Nesse sentido, não só a ideia da livre circulação pela cidade, formulada pelo MPL, contrapóe-se à da SSP como também a pretensão de garantir a segurança dos manifestantes pelo Estado é questionada pelo movimento:

$\mathrm{O}$ que a PM e sua inteligência também parecem não entender é que, como já divulgado pelo movimento, o trajeto será deliberado antes do ato. $\mathrm{O}$ trajeto não pertence apenas ao Movimento Passe Livre, mas será aclamado pela população em assembleia. Assim, o MPL não vê sentido em comparecer a uma reunião para "definir as diretrizes do ato" com uma instituição que se prepara para reprimir uma manifestação legítima antes mesmo que ela aconteça. Esperamos que a polícia cumpra sua função de garantir que o direito de todas e todos sejam respeitados [sic], inclusive e principalmente daqueles que lutam por seu direito à cidade e por uma vida sem catracas. ("Por que não vamos nos reunir com a polícia”, nota do MPL de 7 de janeiro de 2015).

No dia em que foi realizada a primeira observação participante de um protesto do MPL (9 de janeiro de 2015), corria entre manifestantes a in- formação de que a PM não deixaria o ato adentrar a Avenida Paulista. A cerca de quatro quadras do cruzamento entre a Rua da Consolação, por onde seguia o ato, e a Avenida Paulista, foram lançadas bombas de gás e de efeito moral pela PM. Alguns poucos jovens com rostos cobertos, descendo correndo ou sobre skates, vindos da Avenida Paulista no sentido contrário ao da manifestação, chutavam portas de estabelecimentos comerciais e lixeiras; a linha de policiais da Força Tática se posicionou com escudos e atiradores de bombas de efeito moral e de gás, alguns voltados para a manifestação e outros voltados para os jovens que desciam no sentido oposto, e começaram a atirar bombas. Rapidamente as pessoas começaram a correr, assim como os policiais: alguns em direção aos jovens que desciam a Rua da Consolaçáo de encontro à manifestação, e os demais em direção aos manifestantes.

Os manifestantes corriam para qualquer lado, procurando fugir das bombas e dos policiais pelas ruas transversais ou se abrigando nos estabelecimentos comerciais que já estavam abertos. Em determinado momento, o pesquisador-observador também se viu obrigado a procurar refúgio e, quando a situação era um pouco mais calma, voltou a circular pela Rua da Consolação e por algumas de suas ruas transversais. Manifestantes andavam em pequenos grupos pela rua, viaturas policiais fechavam o fluxo de trânsito e eventualmente subiam e desciam a avenida em alta velocidade.

Foi constatada a presença de grupos de pessoas presas sentadas na calçada, cercados por policiais; a mesma cena podia ser vista em várias das ruas transversais, logo no primeiro ou no segundo quarteirão para quem deixava a Rua da Consolação em direção a uma dessas ruas, que já estavam bloqueadas pela polícia. Outros manifestantes, profissionais da imprensa e mesmo advogados eram impedidos de se aproximar das pessoas presas.

Essa estratégia de dispersão e prisão foi descrita por um dos advogados entrevistados como um resultado ao aperfeiçoamento do trabalho policial de repressão, e como um aprendizado da própria PM ainda nos protestos de junho de 2013:

Em junho foi um baita laboratório [...] para eles incrementarem e se atualizarem. Essa táti- 
ca de... o próprio bloco da Polícia Militar que faz isso não existia antes... eram os "robocops" lá, é que atuavam no braço. Que foi uma organização dentro da Polícia Militar de cada batalhāo pegar os seus... os seus componentes ali que têm alguma habilidade marcial e treiná-los para imobilizar pessoas. [...] Entáo houve uma... uma reorganização tremenda, tremenda da... da... das forças repressoras depois de 2013. Mas, assim, brutal. Você olha o dia 6 de junho e olha janeiro de 2015, a diferença da repressão é... é gritante. E eles aprenderam, eh... foram várias técnicas que eles forjavam a partir de lá. [...] Aí ficou muito claro uma nova técnica que eles inventaram de não... não reprimir em bloco. Eles reprimem cercando e depois que eles estouram uma manifestação, eh... eles rodam em trevo, no entorno, com três... com três carros do Choque em pontas diferentes, como se eles estivessem em um triângulo e rodando meio que assim, sabe? (Entrevista com Advogado 7).

Contudo, o mesmo advogado entrevistado alertou: essa técnica não tem por objetivo necessariamente a prisão, mas tão somente a dispersão dos manifestantes e evitar que eles se agrupem novamente de modo a retomar o protesto, o que é confirmado pelo trecho já citado da entrevista com o policial militar. Essa mudança de tática em relação aos primeiros dias de 2013 talvez explique a redução das cenas de confronto direto entre policiais e manifestantes, e também do número de prisôes: de acordo com o jornal Folha de S. Paulo, o ato de 9 de janeiro de 2015 teve 53 detidos em mais de 5.000 manifestantes. ${ }^{16}$

Esse modo de atuação mais eficaz (em termos de dispersão da manifestação em curto período de tempo) e econômico (em termos de contingente, violência física direta e prisões) também pôde ser observado na manifestação do dia 16 de janeiro de 2015 , que dessa vez seguiu em direção à sede da Prefeitura de São Paulo no Viaduto do Chá ${ }^{17}$; após serem ouvidas algumas bombas onde se concentravam os manifestantes, na frente da sede do Executivo municipal, foi possível ver a multidão atravessando o Viaduto do Chá em direção ao Theatro Municipal, enquanto a multidáo que estava na frente do Municipal e a parte da marcha que ainda estava chegando naquele ponto pela Rua Xavier de Toledo começou a correr e a se dispersar pelas ruas transversais daquela região do centro da cidade. Em pouco tempo o espaço estava vazio, os distúrbios, encerrados, e alguns ônibus da PM saíam cheios de manifestantes detidos. Um cenário bastante diferente da repressão desordenada e prolongada que foi vista nos primeiros protestos de 2013, o que demonstra não só a força que a interpretaçáo sobre a violência praticada pela PM contra manifestantes e jornalistas teve na mudança de apoio da opinião pública e na dinâmica dos protestos (Secco, 2013), mas também um verdadeiro aprendizado pela PM desde então. ${ }^{18}$

A observação da atuação policial nesses protestos, combinada com dados extraídos das entrevistas realizadas, permite-nos algumas consideraçôes a respeito dos processos de criminação e incriminação pela PM no momento das prisóes que originam procedimentos criminais formais, por meio dos quais novos processos de criminação e incriminação têm lugar. Em primeiro lugar, e como o próprio soldado entrevistado afirmou, no momento do protesto não se trata de uma individualização do processo de criminação/incriminação, mas sim de uma imposição violenta do fim da manifestação e $\mathrm{da}$ dispersão dos manifestantes em decorrência de um outro ato de criminaçãolincriminação pontual e isolado, que justificaria a repressão generalizada.

Além disso, as prisóes se mostram claramente mais um mecanismo de contenção e desmobilização da manifestação do que um ato individualizado e juridicamente necessário em função da verificação da ocorrência em flagrante de um crime. Dessa forma, a já denunciada "prisão para averiguação", em geral ocorrida antes mesmo da manifestação ou durante um protesto, nesse contexto ganha o sentido de uma "prisão para desmobilização". Como pôde ser verificado na observação in loco dos protestos, e como foi relatado por manifestantes e advogados entrevistados, muitos manifestantes são soltos ainda no local da prisão, ou logo que chegam às delegacias, mesmo sem qualquer acusação formal ou registro da ocorrência pela PC; isso também é evidente na discrepância entre o número de pessoas presas e o número de inquéritos e açóes penais mes- 
mo nos dias considerados como os de maior repressão policial em junho de 2013. Como já verificado em outros estudos sobre policiamento de protestos, o trabalho policial de repressão nesses contextos não se guia necessariamente (tão pouco oficialmente) pela repressão a ilegalidades ou a comportamentos individuais, mas sim pela contenção do dissenso político e pela confrontação coletiva (P. A. J. Waddington, 1996, 1999).

\section{Os inquéritos policiais e as açôes penais}

Dos procedimentos criminais considerados para análise comparativa de seus fluxos de tramitação (Procedimentos 1, 4, 5 e 6), não há nenhum contra apenas um único acusado. Foram identificados 18 acusados no total, sendo que o Procedimento 4 tem dez acusados, o Procedimento 6 tem quatro acusados, e os outros dois procedimentos têm dois acusados cada um. Verifica-se, portanto, um esforço de criminalização da ação coletiva, destacando a funcionalidade da atribuição do crime de formação de quadrilha ou bando para essa finalidade, já que tal infração (conforme sua definição anterior à Lei das Organizaçôes Criminosas) consistia tão somente na reunião de quatro ou mais pessoas voltadas para a prática de crime ${ }^{19}$.

Todas as prisões foram feitas em flagrante delito, por policiais militares que conduziram os acusados à delegacia; no registro da ocorrência na delegacia, as prisóes foram testemunhadas apenas por soldados da PM. Na análise do conteúdo dos inquéritos, é possível perceber que a versão apresentada pelos policiais autores da prisão ("condutores", na linguagem formal) é sempre confirmada pelos policiais testemunhas, muitas vezes com cópia literal das declaraçóes. Quanto ao local da prisão, apenas no Procedimento 5 o relato dos policiais demonstra que a prisão em flagrante delito não aconteceu nos mesmos lugar e momento do crime. Em todos os procedimentos houve a confirmação da prisão pelo delegado, e em dois deles (Procedimentos 1 e 5) há informação sobre o arbitramento da fiança.

Foi também verificada na análise a apreensão de objetos no momento da prisão. Objetos foram apreendidos nos Procedimentos 4 e 6, todos eles encaminhados à perícia. Foram listados dez di- ferentes tipos de objeto apreendido: tinta spray e máscara aparecem em dois procedimentos (4 e 6); um instrumento musical foi apreendido no Procedimento 1; touca-ninja, luvas, isqueiro, fogos de artifício e alicate foram apreendidos no Procedimento 6. Os resultados da perícia desses objetos e seus sentidos nos processos de criminalização serão analisados adiante.

Todos os acusados foram ouvidos novamente, após o registro da ocorrência, ainda na fase do inquérito policial, assim como as testemunhas. No Procedimento 5, em que houve uma vítima, esta também foi ouvida em momento posterior ao da prisão. No Procedimento 4 há apresentação de outras testemunhas, diferentes das apresentadas no momento da prisão, que também são ouvidas ao longo da investigação.

Em todos os casos foram solicitadas perícias. Nos inquéritos que tiveram objetos apreendidos pelos policiais, estes também foram todos encaminhados para análise pericial. No Procedimento 5, no qual não houve apreensão de objetos, a perícia foi relativa à lesão corporal e ao dano ao patrimônio público. Nenhuma perícia é conclusiva sobre a ocorrência dos crimes ou sobre a autoria dos crimes. No Procedimento 5 a perícia foi inconclusiva, e nos outros três procedimentos só há conclusão referente à existência de dano, sem identificação de autoria ou causas, ou sobre a possibilidade, em tese, de uso dos objetos apreendidos para a prática dos referidos danos.

A atuação de advogados de defesa durante o inquérito também foi analisada. Apenas no Procedimento 1 não há atuação da defesa nessa fase, e nos demais a defesa é feita por advogados particulares. O que é majoritariamente discutido pelas defesas em suas intervençôes formais nos inquéritos é a existência ou não dos alegados crimes e a possibilidade de participação dos acusados. No Procedimento 4 há pedido da defesa de oitiva de novas testemunhas, o que foi negado pelo delegado. Muitas das intervenções formais, por petições escritas e protocoladas dos advogados, são pedidos para extração de cópias e de retirada dos autos para acompanhamento do inquérito.

O relatório do inquérito é conclusivo nos Procedimentos 4 e 6 ; ambos concluem pela ocorrência 
do crime, mas apenas no Procedimento 6 há também conclusão acerca da autoria de crime. Não há nas conclusôes dos relatórios acréscimo de acusação por crimes diferentes daqueles registrados no momento da prisão em flagrante.

São ofertadas denúncias pelo MP em apenas dois casos, que seguiram então como açóes penais após a fase de inquérito policial (Procedimentos 1 e 5), sendo que no Procedimento 5 a denúncia é feita por uma quantidade menor de crimes que os registrados na fase policial. Não há registro, no conteúdo das denúncias, da incorporação de elementos probatórios além daqueles que já constavam do auto de prisão em flagrante; não há pedido de oitiva de testemunhas diferentes daquelas ouvidas na fase policial; também não há pedidos de prisão provisória.

As denúncias do MP naqueles dois procedimentos foram recebidas pelos juízes, contra todos os acusados e por todos os crimes denunciados. Há defesa prévia em todos os casos, inclusive com participação de novos advogados, diferentes daqueles atuantes no inquérito, no Procedimento 5 . Como é da praxe judicial, nas defesas prévias são discutidas questōes processuais e apresentadas novas testemunhas, sem debates substantivos sobre o caso.

Além da defesa prévia, e antes das alegaçóes finais, só há manifestaçôes da defesa no Procedimentos 5 para troca de testemunhas e para solicitação de perícias, pedidos esses negados pelo juiz. Não há notícia nos autos analisados de impetração de habeas corpus ou de outros tipos de recursos durante a ação penal que se desenrolou naqueles dois procedimentos.

Nesse mesmo intervalo processual há manifestaçóes do MP, que se limitam a contestar os pedidos feitos pela defesa e reforçar a tese apresentada na denúncia, o que significa que não há nenhum tipo de pedido inovador no sentido do esclarecimento dos fatos.

No Procedimento 1 há informação de perícia na fase judicial, no que se refere ao dano alegado, resultando inconclusiva (como já ocorrera na fase policial). Esse procedimento é concluído com acordo de suspensão condicional da pena, aceito e cumprido até $\mathrm{o}$ fim ${ }^{20}$.

O Procedimento 5 segue o fluxo processual regular até a fase de sentença. Nas alegaçóes finais da acusação o MP pede a absolvição dos acusados. Nas alegaçóes finais da defesa, feitas pelos mesmos advogados do início dos processos, além da absolvição não há nenhum pedido subsidiário. A sentença do juiz absolve todos os réus, de todas as acusações, com base no artigo 386, inciso IV do Código de Processo Penal (em decorrência de se estar provado que o réu não concorreu para a infração penal).

Seja nos inquéritos inconclusos ou arquivados, seja nas açóes penais que resultaram em absolvição ou extinção do processo, o resultado geral indica a não responsabilização formal e definitiva de manifestantes presos (ou seja: não há juízo jurídico definitivo de responsabilidade, nem condenação transitada em julgado). Em um balanço geral dos diferentes caminhos processuais verificados pela pesquisa dos procedimentos selecionados, seria possível afirmar, portanto, que embora a discricionariedade da PM seja determinante na produção de criminação (isto é, a atribuição de caráter criminoso a certas condutas no momento da prisão em flagrante e reproduzida no inquérito policial e pela denúncia do MP) e de incriminaçâo (ou seja, uma imputação imediata e altamente discricionária da conduta tida por criminosa a indivíduos presos no momento dos protestos, também reproduzida sem alterações no inquérito e na denúncia pelo MP), o prosseguimento dos procedimentos criminais em bases menos (o inquérito) ou mais formalizadas (a ação penal) garante maior espaço para o exercício do contraditório e para uma responsabilização individualizada baseada em provas e, por isso, ao menos em tese, passível de ser enfrentada em termos de um procedimento judicial formal democrático.

Contudo, essa afirmaçáo deve ser relativizada por dois outros dados da realidade dos protestos e do funcionamento da justiça criminal, revelados pela pesquisa. $\mathrm{O}$ primeiro diz respeito à importância simbólica da dramaticidade e da intensidade do momento do protesto para sua força política (Della Porta, 2008; Della Porta e Diani, 2006), ao seu caráter performático e estético (Bucci, 2016) e à sua capacidade de mobilizar emoçóes (Jasper, 2016), o que nos obriga a atribuir também à criminação e à incriminação imediatas dos protestos (por meio das prisóes em flagrante ou para averiguação) um peso simbólico que supera sua aparente precariedade ju- 
rídica e as possibilidades de resistência apresentadas pelo processo penal formal dela decorrentes.

Esse efeito se verifica não somente na prisão imediata de manifestantes, mas também no peso moral das acusaçóes que persistem enquanto tramitam os procedimentos, relatado por manifestantes entrevistados, e que reforçam a ideia de que o próprio processo criminal, independentemente de seu resultado, pode servir como uma espécie de sanção sobre os acusados ${ }^{21}$. Além disso, é importante mencionar a importância da mídia e da opiniáo pública para a compreensão dos processos de criminalização (Gomes, 2015; Reiner, 2002; Xavier, 2015), elemento empiricamente verificado na pesquisa, especialmente nas referências feitas pelos advogados (ver Gráfico 1), em sua participação na criminalização simbólica de manifestantes presos e processados, e também no seu papel na produção da sujeição criminal dos chamados "vândalos".

$\mathrm{O}$ segundo dado tem a ver justamente com os processos de sujeição criminal, e diz respeito ao tipo de classificação jurídica do conflito político e de seus protagonistas que a criminação e a incriminação imediatas operam e que persistem nessa indefinição da situação de prisóes sem prosseguimentos formais, inquéritos ainda em andamento e de poucas sentenças judiciais de mérito. Essa classificação jurídica, baseada na acusação por crimes patrimoniais e contra a ordem pública, repercute para além dos casos individuais e dos autos processuais, reverberando nos discursos públicos da SSP e da imprensa sobre a legitimidade dos protestos e sobre a necessidade de diferenciação entre "manifestantes pacíficos" e "vândalos", ou entre "manifestantes" e "cidadãos" ou "trabalhadores". Trata-se, portanto, de um processo de sujeiçáo criminal, caracterizado pela criminalização de sujeitos sociais, de maneira preventiva e independente da comprovação da prática de atos criminosos. ${ }^{22}$

Os dados sobre os fluxos dos procedimentos criminais confirmam, para o problema específico da criminalização dos protestos, outros resultados de pesquisa sobre o funcionamento da justiça criminal em geral, e do inquérito policial, em especial. Conforme se depreende na literatura sociológica sobre o inquérito policial, a centralidade da atuação policial na condução das investigações é enorme, com resultados posteriores na fase judicial da responsabilização penal (Misse, 2010b, 2011; Ratton et al., 2011). Com exceção das medidas restritivas de liberdade (como no caso das prisóes preventivas), em que uma decisão judicial é obrigatória, a PC conduz suas atividades de maneira autônoma e sem qualquer tipo de subordinação ao Judiciário ou ao MP. Este último, apesar de legalmente estar imbuído do exercício do controle externo da atividade policial, não ocupa papel relevante nesta fase pré-processual, ficando a critério da PC a instauração ou não do inquérito, a produção de provas e a linha investigatória adotada. Este grau de autonomia garantido pela lei coexiste, ainda, com práticas informais de seleção e condução dos casos levados ao seu conhecimento, ampliando a influência e o poder da PC sobre o processo de incriminação.

Outro elemento marcante da dinâmica do inquérito policial no Brasil, analisado pela literatura e verificado também nesta pesquisa, é a centralidade do papel no inquérito policial, próprio de sua natureza cartorial e burocrática, que materializa o procedimento (Misse, Nascimento, Renoldi, Grillo e Neri, 2010). Nos procedimentos decorrentes de prisóes em protestos de junho de 2013, isso se expressa na reprodução literal de depoimentos de policiais autores e testemunhas de prisão em um mesmo registro de ocorrência; no registro de apreensão de objetos e na realização de laudos periciais desses objetos sem qualquer justificativa sobre sua importância para a apuração do crime; e nas manifestações formais e sem maiores efeitos do MP, dos juízes e dos advogados de defesa ao longo do inquérito.

A pouca novidade da fase judicial dos dois procedimentos analisados que a ela chegaram (Procedimentos 1 e 5), em termos de narrativas e de produção de provas, quando comparada com a fase policial, revela outra característica já apontada por estudos sobre o inquérito policial no Brasil: sua particularidade como procedimento administrativo (não judicial), preparatório da persecução penal, uma vez que concentra características de investigação e de formação de culpa, constituindo-se, portanto, como uma pré-instrução criminal, que reverbera em todas as demais fases do fluxo de justiça criminal (Azevedo e Vasconcellos, 2011; Ratton et al., 2011), mas de maneira frouxamente articulada (Vargas e Rodrigues, 2011). 
O inquérito black bloc

Quando comparadas com as dos demais inquéritos analisados nesta pesquisa, as singularidades do "inquérito black bloc" (Procedimento 7) estão na intencionalidade de sua instauração - não um evento específico ou uma prisão em flagrante, mas o objetivo de apurar a existência, as açôes criminosas e a responsabilidade de uma organização criminosa identificada como "os black blocs" - e na forma de conduçáo do trabalho policial de investigação - menos burocrático (mas ainda assim burocrático, como analisaremos na sequência) e menos vinculado aos elementos do flagrante (já que ele não existe) e guiado por aquela intencionalidade política que justificou sua atuação.

Dessas singularidades fundamentais decorrem outras características do trabalho da PC verificáveis naquele procedimento específico. Observou-se que a relação do trabalho da $\mathrm{PC}$ com os "fatos" não se dá como mera reprodução e aceitação de fatos narrados pela PM (como ocorre nos casos anteriormente analisados, decorrentes de prisões em flagrantes), mas com um trabalho próprio que se desenvolve basicamente de quatro formas: a coleta e reunião de informaçôes (basicamente, Boletins de Ocorrência e depoimentos) de outros procedimentos criminais que resultaram de prisóes em flagrante realizadas durante protestos; o acompanhamento in loco de manifestaçôes; o acompanhamento de indivíduos, grupos e manifestaçôes políticas feitas nas redes sociais, especialmente o Facebook; a intimação e a tomada de depoimentos presenciais de ativistas identificados em outros procedimentos criminais ou nas redes sociais, não raro agendados para dias em que os protestos estavam previstos.

A investigação no site Facebook parece ser o principal trilho do trabalho policial nesse procedimento específico. Pessoas que confirmaram participaçáo em protestos convocados por meio da internet ou que "curtiram" páginas relacionadas aos "black blocs" foram intimadas a depor, e suas conexôes na rede social (relaçóes de "amizade" ou de "seguir" uma determinada página ou perfil) são exploradas nos depoimentos a fim de se identificar conexôes entre indivíduos que configurem a ação coletiva para a prática de crimes.
Nos depoimentos e na sistematizaçấo de evidências colhidas em páginas do Facebook, destaca-se o foco da PC no questionamento acerca de trajes (roupas pretas e rostos cobertos significariam participação na organização criminosa identificada como "black blocs"), declaraçóes e interesses políticos (filiação a partidos e organizações, palavras de ordem) e, principalmente, acerca da possibilidade de existência de uma organizaçấo criminosa a coordenar a atividade de manifestantes nos protestos de 2013 (com questionamentos específicos sobre membros, liderança, financiamento e possíveis relaçóes dessa organização criminosa com partidos políticos e movimentos sociais). Não há, contudo, nenhuma informaçáo a respeito de perícias ou trabalho de inteligência no sentido de identificar usuários, acessos e redes de conexão virtual para além daquelas informaçôes coletáveis por qualquer leigo por meio do acesso público e regular ao Facebook.

É por meio dessas singularidades que podemos entender a crítica a esse procedimento criminal feita por militantes e advogados, no sentido de denunciar a função de monitoramento, vigilância e desmobilização permanentes, por parte da PC, sobre manifestantes, movimentos sociais e eventos de protestos:

E aí a gente tem toda a estratégia de coleta de informaçáo muito grande, que eu acho que é o que foi feito a partir do inquérito black bloc, que também se desdobra de uma estratégia de intimidação, né? Porque com aquele inquérito, você não só... com aquele inquérito, eles não só coletaram uma leva de informação muito grande, mas também intimidaram uma massa de gente que normalmente comparecia a atos mais ou menos com aquelas características. (Entrevista com Manifestante 1).

Realmente esse inquérito, ele incluiu... eu acho que a gente teve um papel importante de resistência a ele, mas ainda assim eu acho que ele cumpriu bem o papel de tocar o terror nas pessoas. As pessoas ficaram muito assustadas com esse inquérito. Imagina, intimaram mãe para ir depor no DEIC [Departamento Estadual de Investigaçóes Criminais]. O pessoal nem 
sabia o que estava fazendo lá. Isso aí dá medo nas pessoas, né? (Entrevista com Advogado 7).

Dessa forma, a delimitação, ainda que imprecisa, de fatos (atos de "vandalismo" genericamente considerados) e responsabilidades (indivíduos que atuam de maneira organizada) é necessária para a instauração de um inquérito dentro dos padrôes formais e democráticos esperados para o trabalho $\mathrm{da} \mathrm{PC}$, ainda que tais fatos e responsabilidades sejam de difícil apuração e individualização efetivas, como demonstram os procedimentos criminais analisados no tópico anterior. Por outro lado, essa vinculação formal ao processo criminal democrático serve de base para estratégias de vigilância estatal sobre movimentos e ativistas que aproximam a PC de características de uma verdadeira polícia politica: o monitoramento para a coleta e sistematização de informaçóes que possam prevenir o regime político ou o governo de ameaças vindas de grupos politicamente mobilizados (Emsley, 1997; Reznik, 2004). ${ }^{23}$ Tanto é assim que, após vinte e três meses de tramitação, e sendo capaz de permitir o acompanhamento de ativistas e eventos de protestos ao longo de todo esse período - incluindo atos de protestos programados contra a Copa do Mundo, em 2014 - o "inquérito black bloc" foi arquivado pela PC, sendo inconclusivo quanto aos objetivos que levaram à sua instauração, ou seja, a investigação da existência de uma organização criminosa voltada para a prática de atos de vandalismo.

Em declaraçóes prestadas a uma reportagem do jornal Folha de S. Paulo sobre o arquivamento do "inquérito black bloc" ${ }^{24}$, o promotor do MP atuante junto àquele procedimento criminal explicitou a tese que sustentou a existência da investigação por quase dois anos, ao defender prisóes para averiguação, vigilância preventiva sobre pessoas mascaradas e atuação deliberada da PC em classificar atos e indivíduos isolados como parte de uma organização criminosa, independentemente das evidências concretas, apenas com base em uma tese previamente formulada (a da existência da organização criminosa):

"Como havia grande articulação entre eles, houve a ideia de enquadrá-los no artigo 288$A$, que vem a ser organizar grupo para praticar qualquer dos crimes previstos no Código Penal. Isso caía como uma luva, mas muito delegados não agiram assim”, afirma o promotor Marcelo Barone, que atuou no caso.

Para ele, a polícia erra agora como erra nas manifestaçóes passadas ao não levar os mascarados imediatamente à delegacia para averiguação. $\mathrm{Na}$ opinião de Barone, isso poderia ser feito a partir do poder de polícia e sua prerrogativa de fiscalizar e se anteceder à prática do crime tese controversa entre advogados.

"Por que uma pessoa mascarada está numa manifestação pacífica? Acho um absurdo a PM só fotografar e deixar o cara lá. No momento em que se constitui um grupo para cometer crimes, o crime está consumado", afirma.

Apesar dessas singularidades, há características do "inquérito black bloc" que o aproximam dos padróes verificados nesta e em outras pesquisas sobre os fluxos do inquérito policial no Brasil: o registro formal de todos os passos da investigação, com uma profusão de documentos impressos; a replicação de informaçôes (cópias de outros Boletins de Ocorrência, cópias de mandados de intimação, cópias de documentos de identificação civil etc.); as manifestaçôes burocráticas e procrastinatórias dos advogados de defesa (apresentação de procuração para representação dos interesses dos acusados, pedidos de vistas, pedidos de extração de cópias, pedidos de adiamento de oitivas).

Em suma, e com exceção do primeiro volume do referido inquérito - que é composto basicamente da portaria de instauração, de fotos e de um relatório de diligências feitas pela equipe de investigação no local de um protestos e de uma enorme quantidade de mandados de intimação (seguidos das respectivas certidóes de sucesso ou insucesso na localização dos acusados) -, todos os seis volumes seguintes do inquérito são compostos basicamente de termos de declaraçóes prestadas pelos acusados perante a PC, seguidos de cópias de seus documentos pessoais e de cópias das páginas de seus perfis no Facebook, incluindo lista de amigos, interesses, mensagens, fotos etc. A partir do oitavo volume começam a aparecer 
nos autos cópias de novos boletins de ocorrência de outros protestos ocorridos após a instauração do "inquérito black bloc", registrados em outras delegacias e que passam a compor o acervo de registros de ocorrências criminais decorrentes de protestos colecionada no procedimento do DEIC; também surgem cópias de notícias de jornal a respeito de atos de vandalismo praticados em protestos ocorridos após a instauração do Procedimento $7^{25}$.

Dessa forma, é possível dizer que o padrão formalista e burocrático do "inquérito black bloc" (comum a outros procedimentos aqui analisados e ao padrão do inquérito policial no Brasil em geral) é instrumentalizado em benefício de sua singularidade, ou seja: a extensão do inquérito no tempo, a alta discricionariedade da PC na sua condução, a profusão de ritos e registros formais que submetem acusados e seus advogados, a ausência de práticas investigativas que não sejam a mera produção e reprodução de narrativas colhidas em depoimento. Tudo isso permitiu que o inquérito n. 1/2013 do DEIC servisse de instrumento de monitoramento e vigilância permanente de ativistas, movimentos e atos de protestos ocorridos ao longo de sua tramitação, sem que se chegasse a qualquer conclusão efetiva sobre a autoria de crimes ocorridos em protestos ou a existência de uma organização criminosa que abarcasse todos os indivíduos intimados e ouvidos pela $\mathrm{PC}$ e todos os atos criminosos registrados nos diferentes boletins de ocorrência vindos de outras delegacias e que passaram a compor o acervo "probatório" daquele procedimento.

\section{Consideraçóes finais}

Os resultados de pesquisa apresentados anteriormente permitem algumas conclusóes sobre o objeto estudado. A primeira delas é a de que a opção, em um primeiro momento, por um conceito amplo de criminalização (extraído da criminologia, sem necessariamente se vincular ao problema específico dos protestos ou dos movimentos sociais, mas a ele atento por meio de um diálogo com a literatura pertinente) se mostrou útil para compreender e conceituar uma questão muito debatida, mas pouco estudada pela ciência política, pelo direito, pela sociologia do direito ou pela criminologia.
Nesse sentido, o emprego dos operadores analíticos sugeridos por Misse, que estabelecem diferenças entre processos distintos de criminalização (criminalização, criminação, incriminação, sujeição criminal), permitiu que a análise desenvolvida nesta pesquisa identificasse e explorasse as diferentes dimensóes e mecanismos do que chamamos, de maneira genérica, de criminalização dos movimentos sociais. Sobre isso, e substantivamente falando, os resultados apontam para algumas consideraçóes importantes sobre o fenômeno na criminalização dos protestos:

(i) O predomínio da atividade policial, em especial da PM nos processos de criminação e incriminação, com efeitos imediatos na dispersão de manifestaçóes pelo uso da força, e com efeitos diferidos no tempo dos inquéritos policiais burocraticamente conduzidos pela PC basicamente suportados pelos elementos apresentados pela própria PM no momento da formalização da prisão em flagrante.

(ii) O alto grau de discricionariedade da PM no arbitramento de supostos conflitos de direitos (de manifestação, de ir e vir) e no juízo de legitimidade das manifestaçóes, operaçóes realizadas de maneira pouco controlada formalmente e baseada em conteúdos autoritários sobre ordem e cidadania.

(iii) A possibilidade de uso intimidatório e dissuasivo do instrumento do inquérito policial pelas instituiçôes de justiça e de segurança, mesmo diante da precariedade daquele instrumento na efetivação de um trabalho técnico-científico de investigação que não seja mera reprodução cartorial de narrativas pré-determinadas e de papéis aptos a eventualmente instruírem futuras ações judiciais penais.

(iv) $\mathrm{O}$ fato de que esse uso intimidatório e dissuasivo se sustenta tanto nas características gerais do inquérito policial no Brasil, já identificadas pela literatura (cartorialismo, formalismo, discricionariedade do delegado, articulação frouxa com as instituiçóes judiciais), quanto por direcionamentos políticos explícitos, como no caso do "inquérito black bloc", que aproximam a PC de verdadeira polícia política. 
A especificidade da criminalização dos movimentos sociais existe, contudo, quando se entende os diversos processos de acusação e classificação como sendo estruturados em torno das conceituaçóes dos protestos e dos manifestantes como atos e sujeitos criminosos ou, de maneira oposta, como expressão do direito de manifestação feita por sujeitos políticos legítimos. Nesse aspecto, as principais conclusóes da pesquisa são:

(i) A alta discricionariedade da PM no arbitramento do potencial conflito de direitos (de manifestação, de ir e vir) abre espaço para concepçóes autoritárias de ordem e limitadoras da participação política a roteiros institucionais específicos, previstos ou não de maneira formal-legal.

(ii) As fases posteriores do fluxo de justiça da criminalização dos processos não são capazes de reverter as classificaçóes e os juízos feitos pela PM no momento da repressão, assim como seus efeitos imediatos desmobilizadores, seja pela precariedade da conexão entre investigação (inquérito) e responsabilização (ação penal), seja pela mobilização deliberada de procedimentos criminais para fins de vigilância, monitoramento, dissuasão e desmobilização políticas.

Em última análise, essas práticas políticas e judiciais podem ter efeitos duradouros na delimitação do espaço e das açóes políticas consideradas legítimas - o que é problemático não pela exigência normativa de delimitação do político e de seus critérios de legitimidade, mas pelo fato de que, da forma como se estrutura, tal delimitação se dá em meio a processos criminalizantes abundantes em violência física e simbólica, reprodutores de desigualdades, baseados em concepçôes autoritárias de ordem pública e pouco suscetíveis à deliberação democrática e igualitária.

\section{Notas}

1 Trata-se do projeto de pesquisa "Conflito político e sistema de justiça: a judicialização criminal dos protestos urbanos em São Paulo (2013-2015)”, financiado pela
Fundação de Amparo à Pesquisa do Estado de São Paulo (Auxílio Regular, processo n. 2015/00255-4), a quem agradecemos pelo suporte necessário à investigaçáo.

2 Sobre as formas de organização e atuaçáo de advogados nos protestos de junho de 2013 em São Paulo, incluindo os profissionais ligados ao MPL, ver artigo anterior resultante do mesmo projeto de pesquisa (Almeida e Noronha, 2017).

3 Todos os entrevistados manifestaram seu consentimento com a realização da entrevista e seu uso para fins acadêmicos, consentimento esse registrado na gravação e na transcrição das entrevistas.

4 A pesquisa que deu origem a este artigo também analisou processos de sujeição criminal na repressão aos protestos, mas dadas as peculiaridades do fenômeno e os limites desta exposição, preferimos centrar a análise deste artigo nos processos de criminalização mais diretamente relacionados à prática imediata de agentes, instituições e procedimentos formais de segurança e justiça criminal.

5 Um exemplo bastante recente: após protestos em Brasília contra a aprovação de uma Proposta de Emenda Constitucional que estabeleceria teto aos gastos públicos, no ano de 2016, a Secretaria de Segurança Pública do Distrito Federal chegou a anunciar que aplicaria a Lei Antiterrorismo contra os 72 manifestantes detidos; a propósito, ver a reportagem no site da revista Exame, de 14 de dezembro de 2016, disponível em https://exame.abril.com.br/brasil/detidos-em-protesto-podem-ser-enquadrados-na-lei-antiterrorismo, consultada em 8 out. 2019.

6 Sobre isso, ver a reportagem de Isabela Vieira no site da Empresa Brasil de Comunicação, de 25 de outubro de 2013, disponível em www.ebc.com.br/noticias/ brasil/2013/10/justica-global-recorre-a-oea-contra-prisao-de-manifestantes-no-rio, consultada em 8 out. 2019.

7 Ver a reportagem de Felipe Pontes no site da Agência Brasil, de 3 de agosto de 2016, disponível em http:// agenciabrasil.ebc.com.br/geral/noticia/2016-08/justica-usa-lei-de-organizacao-criminosa-para-prender-membros-do-mst-em-goias, consultada em 8 out. 2019.

8 Ver, por exemplo, a Lei n. 6.528/2013, aprovada pela Assembleia Legislativa do Estado do Rio de Janeiro, sancionada pelo entáo governador Sérgio Cabral e considerada constitucional pelo Tribunal de Justiça do Rio de Janeiro em 2014.

9 A Lei Complementar Municipal n. 832/2018, da cidade de Porto Alegre, prevê multa a quem bloquear vias públicas para realização de protestos. 
10 É o caso da Lei n. 13.281/2016, que alterou o Código de Trânsito Brasileiro e criou nova infração administrativa, caracterizada pela realização de manifestação sem autorização com bloqueio de via pública.

11 Adotamos aqui uma concepção flexível de campo, particularmente de campo jurídico, empiricamente ancorada no acúmulo de pesquisas sobre o sistema de justiça brasileiro, considerando especialmente o papel das polícias na produção social do direito e da justiça no Brasil; nesse sentido, ver Almeida (2017) e Sinhoretto (2010).

12 Conforme sugerido por Saldaña (2009), a codificação foi feita em dois ciclos: no primeiro, foram privilegiados códigos descritivos (que atribuem sentidos a certos trechos) e códigos in vivo (que reproduzem os termos do próprio discurso), com a finalidade de identificar padróes nos discursos analisados; no segundo ciclo, os códigos foram reorganizados, eventualmente fundidos em códigos mais abrangentes, e a maior parte deles agrupados em famílias de códigos, quando diziam respeito a mençôes diretas às instituiçôes analisadas (por exemplo, quando havia menção expressa à "Polícia Militar" ou à "polícia" em geral), mas também a mençóes a atividades praticadas por aquelas instituiçóes (como, por exemplo, quando se falava em prisão em flagrante ou em violência policial), sejam elas atribuiçôes formais, sejam elas atribuídas pelos próprios grupos em seus discursos sobre as práticas concretas dos protestos; no que se refere à identificação dessas práticas, o agrupamento foi feito sempre que elas representavam práticas exclusivas das instituiçóes analisadas, e nunca quando havia dúvida sobre qual instituição a realizava.

13 A medida de proporção (percentual) foi utilizada aqui tendo por referência o total de ocorrência dos códigos analisados neste momento específico da análise e a um conjunto específico de documentos, e não o conjunto de códigos aplicados a todo o material analisado em todo o percurso da pesquisa. Isso porque os códigos aplicados obedecem a diferentes finalidades analíticas e interpretativas, podendo ser segmentados em conjuntos temáticos ou a grupos ("famílias", em ambos os casos, na terminologia do software utilizado), como foi feito aqui; ou seja, neste gráfico em especial, o conjunto corresponde aos códigos referentes à questão das instituiçôes envolvidas no processo de criminalizaçáo, aplicados ao conjunto de entrevistas realizadas com advogados atuantes naquele processo. Apesar de intuitiva, essa medida e sua análise foram construídas com base em fundamentos das técnicas de codificação (Saldańa, 2009) e de lexicometria aplicada à análi- se do discurso (Conde, 2015). A mesma medida de proporção da ocorrência de códigos foi utilizada em outros gráficos apresentados ao longo deste relatório.

14 Ver reportagem no site do UOL publicada em 13 de junho de 2013, disponível em http://noticias.uol. com.br/cotidiano/ultimas-noticias/2013/06/13/em-dia-de-maior-repressao-da-pm-ato-em-sp-termina-com-jornalistas-feridos-e-mais-de-60-detidos.htm, consultada em 8 out. 2019. É importante mencionar que o ato de 13 de junho é considerado por analistas um ponto de mudança na dinâmica e na percepçáo social dos protestos, devido à enorme repressão policial (que atingiu também muitos jornalistas) e à atração de novos grupos e pautas à manifestação que se seguiu, no dia 17 (Secco, 2013; Viana, 2013).

15 Segundo Fernandez (2008), as estratégias de negociaçáo em torno de trajetos, espaços e horários de protestos levadas a cabo por autoridades estatais podem ser consideradas uma modalidade de controle social soft-line ("linha suave") dos protestos, que pressionam por sua institucionalização.

16 Ver reportagem no site da Folha de S. Paulo, publicada em 9 de janeiro de 2015, disponível em www1.folha. uol.com.br/cotidiano/2015/01/1573103-ato-contra-tarifa-tem-depredacao-e-bombas-de-efeito-moral-32-sao-detidos.shtml, consultada em 8 out. 2019. Segundo a organização não governamental Artigo 19, já em 2013 foi possível verificar uma brusca queda no número de detençóes noticiadas pela imprensa, de 1.212 pessoas em junho para $141 \mathrm{em}$ julho, com 16 detidos em dezembro, após um novo pico de 536 detençôes em outubro. Obviamente, esse número é influenciado pelo grande número de protestos em junho daquele ano, mas se considerarmos uma taxa de detidos por número de protestos noticiados por mês daquele ano, teremos cerca de 4 detidos por protestos em junho; menos de uma pessoas detida por protesto ocorrido em julho; mais de 12 detidos por protestos em outubro (quando foram registrados 42 eventos de protestos, contra 291 em junho); e, de novo, cerca de um detido por protesto em dezembro daquele ano (Artigo 19, [s.d.], 2014).

17 Sobre esse ato e a repressão que se seguiu, ver a reportagem de Eduardo Gonçalves no site da revista Veja do dia 16 de janeiro de 2015, disponível em https://veja. abril.com.br/politica/ato-contra-tarifa-mais-uma-vez-tem-confronto-em-sp, consultada em 8 out. 2019.

18 Processos de aprendizagem decorrentes de experiências concretas de policiamento de protestos são fartamente documentados pela literatura especializada; 
nesse sentido, ver Lofthouse (1996), D. Waddington (1996) e P. A. J. Waddington (1991)"editor”:[\{“dropping-particle":"”,"family":"Critcher","given":"Chas","non-dropping-particle":",",parse-names":false,"suffix":"”\},\{“dropping-particle":", "family":"Waddington","given":"David","non-dropping-particle":",",parse-names":false,"suffix":"”\}],"id":"ITEM-1","issued":\{“date-parts":[[“1996”]]\},"note":"Polícias como próprias dos Estados $\backslash n \backslash n$ Polícia: manutenção da ordem x garantia da lei $\backslash n \backslash n$ Policiamento não é apenas força, é legitimiação e compromisso; repressão acontece especialmente em momentos de crise de he-

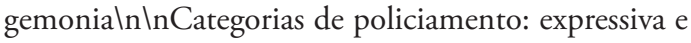
repressiva $\backslash n$ - Expressiva: serviço público e imparcial associado ao bem estar comunitário (resolução de pequenos conflitos, polícia comunitária.

19 obre a funcionalidade da aplicação do crime de formação de quadrilha para a criminalização da ação coletiva, ver Sinhoretto e Almeida (2006).

20 A extinção do processo após suspensão condicional do processo é uma inovaçáo trazida pela Lei n. 9.099/1995, que instaurou os chamados Juizados Especiais Criminais para crimes considerados de menor potencial ofensivo. De acordo com aquele mecanismo, o MP apresenta uma proposta de suspensão do processo, após a denúncia mas antes da sentença, mediante condições que o acusado deve cumprir (comparecimento regular perante o juízo criminal, prestação de serviços à comunidade, proibição de ausência da comarca do processo ou de frequência a certos lugares etc.) por um período; cumpridas as condiçóes, o processo é extinto sem julgamento do mérito, ficando o acusado formalmente livre de uma condenação formal, portanto juridicamente inocente.

21 Sobre isso, embora sob outra perspectiva teórica, ver o clássico trabalho de Feeley (1979).

22 O processo de sujeição criminal não será analisado em detalhes neste artigo; ver nota 4.

23 Essa hipótese já foi previamente explorada em estudo sobre o "inquérito black bloc" realizado do ponto de vista do direito constitucional e do direito penal (Oliveira, 2017).

24 Ver reportagem de Lucas Ferraz no site da Folha de S. Paulo, de 25 de janeiro de 2016, disponível em www1. folha.uol.com.br/cotidiano/2016/01/1733111-principal-investigacao-sobre-black-blocs-termina-sem-acusar-ninguem.shtml, consultada em 8 out. 2019.

25 À época em que tivemos acesso às cópias desse inquérito, ele ainda não estava concluído; por isso, nossa análise se restringe a cópias obtidas e a informações posteriores sobre seu arquivamento, divulgadas pela imprensa.

\section{BIBLIOGRAFIA}

ALMEIDA, Frederico de. (2017), "A noção de campo jurídico para o estudo dos agentes, práticas e instituiçóes judiciais”, in F. Engelmann. (org.), Sociologia Politica das Instituiçóes Judiciais. Porto Alegre, Editora da UFRGS/CEGOV.

ALMEIDA, Frederico de e NORONHA, Rodolfo. (2017), "Advogando nas ruas: advocacia em protestos no Rio de Janeiro e em São Paulo (2013-2015)". Caderno Eletrônico de Ciências Sociais, 4 (2): 5-28.

ARTIGO 19. ([S.D.]), Protestos. Disponível em: http://protestos.artigo19.org/projetos.php, consultado em 8 out. 2019.

ARTIGO 19. (2014), Protestos no Brasil 2013. Disponível em https://artigo19.org/ blog/2014/06/23/relatorio-protestos-no-brasil-2013, consultado em 8 out. 2019.

AZEVEDO, Rodrigo Ghiringhelli de e VASCONCELLOS, Fabiana Bestetti de. (2011), "O inquérito policial em questão: situação atual e a percepção dos delegados de polícia sobre as fragilidades do modelo brasileiro de investigação criminal”. Sociedade e Estado, 26 (1): 59-75.

BECKER, Howard S. (2014), "A epistemologia da pesquisa qualitativa". Revista de Estudos Empiricos em Direito, 1 (2): 184-198.

BIERNACKI, Patrick \& WALDORF, Dan. (1981), "Snowball Sampling: Problems and Techniques of Chain Referral Sampling". Sociological Methods \& Research, 10 (2): 141-163.

BOURDIEU, Pierre. (2007), O poder simbólico, 10. ed. Rio de Janeiro, Bertrand Brasil.

BRINGEL, Breno e PLEYERS, Geoffrey. (2015), "Junho de 2013... dois anos depois". Nueva Sociedad, especial em português, 4-17.

BUCCI, Eugênio. (2016), A forma bruta dos protestos: das manifestaçôes de junho de 2013 à queda de Dilma Rousseffem 2016. São Paulo, Companhia das Letras. 
CONDE, Dirceu Cleber. (2015), "Lexicometria e análise do discurso". Revista da ABRALIN, 14 (2): 235-254.

DELLA PORTA, Donatella. (1999), "Movimientos Sociales y Estado: algunas ideas en torno a la represión policial de la protesta”, in $\mathrm{D}$. McAdam, J. D. McCarthy \& M. N. Zald. (org.) Movimientos Sociales Perspectivas Comparadas: oportunidades politicas, estructuras de movilización y marcos interpretativos culturales, Madrid, Ediciones Istmo.

DELLA PORTA, Donatella. (2008), "Eventful protest, global conflicts". Conference of the Nordic Sociological Association.

DELLA PORTA, Donatella \& DIANI, Mario. (2006), Social Movements: an introduction, 2. ed. Hoboken, Willey-Blackwell.

EMSLEY, Clive. (1997), "Introduction: Political police and the European Nation-State in the 19th century", in M. Mazower. (org.), The Policing of Politics in the Twentieth Century: Historical Perspectives. Providence, Berghahn Books.

FEELEY, Malcolm (1979), The Process is The Punishment: Handling Cases in a Lower Criminal Court. New York, Russell Sage Foundation.

FERNANDEZ, Luis A. (2008), Policing Dissent: Social Control and the Anti-Globalisation Movement. New Brunswick, Rutgers University Press.

FRANCE, Guilherme de Jesus. (2017), As origens da Lei Antiterrorismo: os tortuosos caminhos da localização das normas internacionais de combate ao terrorismo no Brasil. Dissertação de Mestrado. Rio de Janeiro, Escola de Ciências Sociais da Fundação Getulio Vargas.

GOMES, Marcus Alan. (2015), Midia e sistema penal: as distorçôes da criminalização nos meios de comunicação. Rio de Janeiro, Revan.

JASPER, James M. (2016), Protesto: uma introdução aos movimentos sociais. Rio de Janeiro, Zahar.

JUSTIÇA GLOBAL, Instituto de Defensores de Direitos Humanos e Centro de Assessoria Jurídica Popular Mariana Criola. (2013), "Lei de Segurança Nacional é uma violência contra a democracia brasileira". Brasil de Fato. Disponível em www.brasildefato.com.br/node/26305, consultado em 8 out. 2019.
LACEY, Nicola. (2007), "Legal construction of crime”, in M. Maguire, R. Morgan \& R. Reiner (orgs.), The Oxford Handbook of Criminology, 5. ed. Oxford, Oxford University Press.

LACEY, Nicola. (2013), "The rule of law and the political economy of criminalization". Punishment \& Society, 15 (4): 349-366.

LIMA, Renato Sérgio de; SINHORETTO, Jacqueline e BUENO, Samira. (2015), "A gestão da vida e da segurança pública no Brasil”. Revista Sociedade e Estado, 30 (1): 123-144.

LOFTHOUSE, Michael. (1996). "The core mandate of policing”, in C. Critcher \& D. Waddington. (orgs.), Policing Public Order: Theoretical and Practical Issues. Aldershot, Avebury.

MISSE, Michel. (2008), "Sobre a construção social do crime no Brasil: esboços de uma interpretação", in M. Misse. (org.), Acusados e acusadores: estudos sobre ofensas, acusaçóes e incriminaçôes. Rio de Janeiro, Revan.

MISSE, Michel. (2010a), "Crime, sujeito e sujeição criminal”. Lua Nova, 79: 15-38.

MISSE, Michel. (org.). (2010b), O inquérito policial no Brasil: uma pesquisa empírica. Rio de Janeiro, NECVU/IFCS/UFRJ; Booklink.

MISSE, Michel. (2011), "O papel do inquérito policial no processo de incriminação no Brasil: algumas reflexóes a partir de uma pesquisa”. Revista Sociedade e Estado, 26 (1): 15-27.

MISSE, Michel. (2014), "Sujeição criminal", in R. S. de Lima, J. L. Ratton e R. G. de Azevedo. (orgs.), Crime, polícia e justiça criminal no Brasil. São Paulo, Contexto.

MISSE, Michel; Nascimento, Andréa Ana do; Renoldi, Brígida; GRILLO, Carolina Cristoph e NERI, Natasha Elbas (2010), "O inquérito policial no Rio de Janeiro: mudanças recentes, alcances, tradiçóes e especificidades", in M. Misse. (org.), O inquérito policial no Brasil: uma pesquisa empírica. Rio de Janeiro, NECVU/IFCS/UFRJ; Booklink.

OLIVEIRA, Bruno Almeida de. (2017), "Inquérito policial black bloc: instrumento de criminalização de um movimento social". Revista ESMAT, 9 (13): 103-120.

RATTON, José Luiz; TORRES, Valéria e BASTOS, Camila. (2011), "Inquérito policial, sis- 
tema de justiça criminal e políticas públicas de segurança: dilemas e limites da governança”. Revista Sociedade e Estado, 26 (1): 29-58.

REINER, Robert. (2002), "Media made criminality: The representation of crime in the mass media”, in M. Maguire, R. Morgan \& R. Reiner. (orgs.), The Oxford Handbook of Criminology, 4. ed. Oxford, Oxford University Press.

REZNIK, Luís. (2004), Democracia e segurança nacional: a polícia política no pós-guerra. Rio de Janeiro, Editora FGV.

SALDAÑA, Johnny. (2009), The Coding Manual for Qualitative Researchers. London, Sage.

SECCO, Lincoln. (2013), "As Jornadas de Junho", in C. Vainer et al., Cidades rebeldes: Passe Livre $e$ as manifestaçóes que tomaram as ruas do Brasil. São Paulo, Boitempo; Carta Maior.

SINHORETTO, Jacqueline. (2010), "Campo estatal de administração de conflitos: múltiplas intensidades da justiça”. Anuário Antropológico, 109-123.

SINHORETTO, Jacqueline e ALMEIDA, Frederico de. (2006), "A judicialização dos conflitos agrários: legalidade, formalidade e política”. Revista Brasileira de Ciências Criminais, 14 (62): 280-334.

SINHORETTO, Jacqueline e LIMA, Renato Sérgio de (2015), "Narrativa autoritária e pressóes democráticas na segurança pública e no controle do crime". Contemporânea, 5 (1): 119-141.

TATAGIBA, Luciana. (2014), “1984, 1992 e 2013. Sobre ciclos de protestos e democracia no Brasil”. Politica \& Sociedade, 13 (28): 35-62.

TINOCO, João Vicente. (2016), A Lei Antiterrorismo e a política de criminalização dos movimentos sociais. Monografia de graduação. Rio de Janeiro, Pontifícia Universidade Católica do Rio de Janeiro.

VARGAS, Joana Domingues. (2007), “Análise comparada do fluxo do sistema de justiça para o crime de estupro". Dados - Revista de Ciências Sociais, 50 (4): 671-697.

VARGAS, Joana Domingues e RODRIGUES, Juliana Neves Lopes. (2011), "Controle e cerimônia: o inquérito policial em um sistema de justiça criminal frouxamente ajustado". Revista Sociedade e Estado, 26 (1): 77-96.
VIANA, Silvia. (2013), "Será que formulamos mal a pergunta?", in C. Vainer et al. Cidades rebeldes: Passe Livre e as manifestaçóes que tomaram as ruas do Brasil. São Paulo, Boitempo, Carta Maior.

WADDINGTON, David. (1996), "Key issues and controversies", in C. Critcher \& D. Waddington. (orgs.), Policing Public Order: Theoretical and Practical Issues. Aldershot, Avebury.

WADDINGTON, Peter Anthony James. (1991), The strong arm of the law: armed and public order policing. Oxford, Oxford University Press.

WADDINGTON, Peter Anthony James. (1994), Liberty and Order. London, UCL Press.

WADDINGTON, Peter Anthony James. (1996), "The politics of public order policing", in $\mathrm{C}$. Critcher \& D. Waddington. (orgs.), Policing Public Order: Theoretical and Practical Issues. Aldershot, Avebury.

WADDINGTON, Peter Anthony James. (1999), Policing citzens. London, UCL Press.

WADDINGTON, Peter Anthony James. (2010), "Political protest and crime", in F. Brookman, M. Maguire, H. Pierpoint \& T. Bennett. (orgs.), Handbook on Crime. Uffculem, Willan Publishing.

WEBER, Max. (1999), Economia e Sociedade. Brasília, Editora Universidade de Brasília.

XAVIER, José Roberto Franco. (2015), “A opinião pública e o sistema de direito criminal: sobre as dificuldades de compreender essa relação complexa”. Revista Brasileira de Ciências Criminais, 23 (112): 149-164.

YANOW, Dvora. (2003), "Interpretive Empirical Political Science: what makes this not a subfield of qualitative methods". Qualitative Methods, 1 (2): 9-13.

YANOW, Dvora. (2015), "Making sense of policy practices: interpretation and meaning". in $\mathrm{F}$. Fischer, D. Torgerson, A. Durnová \& M. Orsini. (orgs.), Handbook of critical policy studies. Cheltenham, Edward Elgar. 


\section{A CRIMINALIZAÇÁO DOS PROTESTOS DO MOVIMENTO PASSE LIVRE EM SÃO PAULO (2013-2015)}

\section{Frederico de Almeida, Filipe Jordão Monteiro e Afonso Smiderle}

Palavras-chave: Movimentos sociais; Protestos; Criminalização; Criminalizaçâo dos movimentos sociais; Junho de 2013

Este artigo apresenta resultados de uma pesquisa que teve por objetivo: (i) suprir lacunas conceituais e analíticas para o estudo da criminalização dos protestos; (ii) compreender os processos de criminalização e os sentidos de práticas e discursos de instituiçôes e agentes de segurança e justiça criminal, movimentos sociais, manifestantes e imprensa, empiricamente verificados na análise de dinâmicas, discursos, documentos e procedimentos administrativos e judiciais de repressão dos protestos. O estudo é focado especificamente nos protestos liderados pelo Movimento Passe Livre em junho de 2013 e janeiro de 2015 na cidade de São Paulo. Por meio de uma análise qualitativa aberta e interpretativa de fluxos processuais, discursos e eventos de protesto, buscou-se identificar a ocorrência dos processos de criminalização, criminação e incriminação de manifestantes e atos de protesto por agentes e instituiçóes estatais.

\section{CRIMINALIZATION OF THE PROTESTS OF MOVIMENTO PASSE LIVRE IN SÃO PAULO (2013-2015)}

\section{Frederico de Almeida, Filipe Jordão Monteiro e Afonso Smiderle}

Keywords: Social Movements; Protests; Criminalization; criminalization of social movements; June 2013

This paper presents the results of a research that aimed the following: (i) to fill conceptual and analytical gaps in the studies of criminalization of protests; (ii) to understand the criminalization processes and the meanings of practices and discourses made by institutions and security or criminal justice agents, social movements, protesters and press, which were empirically verified with the analysis of dynamics, speeches, documents and administrative or judicial procedures of protests repression. The study focuses especially on the protests led by Movimento Passe Livre in June 2013 and January 2015 in the city of São Paulo. Through an open and interpretative qualitative analysis of processual flows, speeches and protest events, we sought to identify the occurrence of criminalization and incrimination of protesters and acts of protest by state agents and institutions.

\section{LA CRIMINALIZATION DES MANIFESTATIONS DU MOUVEMENT PASSE LIVRE* À SÃO PAULO (2013-2015)}

\section{Frederico de Almeida, Filipe Jordão Monteiro et Afonso Smiderle}

Mots-clés: Mouvements sociaux; Manifestations; Criminalisation; Criminalisation des mouvements sociaux; Juin 2013.

Cet article présente les résultats d'une recherche qui visait à: (i) combler les lacunes conceptuelles et analytiques pour l'étude de la criminalisation des manifestations; (ii) comprendre les processus de criminalisation et le sens des pratiques et des discours des institutions et des agents de sécurité et de la justice pénale, des mouvements sociaux, des manifestants et de la presse, vérifiés empiriquement dans l'analyse des dynamiques, des discours, des documents et des procédures administratives et judiciaires pour la répression des manifestations. L'étude est spécifiquement axée sur les manifestations menées par le Mouvement Passe Livre en juin 2013 et janvier 2015 dans la ville de São Paulo. Â travers une analyse interprétative et qualitative ouverte des flux procéduraux, des discours et des manifestations, nous avons cherché à identifier la survenance des processus de criminalisation, d'accusation et d'incrimination des manifestants et des actes de protestation commis par des agents et des institutions de l'État.

* NdT: Mouvement pour les transports publics gratuits 